\title{
Cloud adjustments dominate the overall negative aerosol radiative effects of biomass burning aerosols in UKESM1 climate model simulations over the south-eastern Atlantic
}

\author{
Haochi Che $^{1, \mathrm{a}}$, Philip Stier ${ }^{1}$, Hamish Gordon ${ }^{2, \mathrm{~b}}$, Duncan Watson-Parris ${ }^{1}$, and Lucia Deaconu ${ }^{1}$ \\ ${ }^{1}$ Atmospheric, Oceanic and Planetary Physics, Department of Physics, University of Oxford, Oxford, OX1 3PU, UK \\ ${ }^{2}$ School of Earth and Environment, University of Leeds, Leeds, LS2 9JT, UK \\ a now at: Department of Geophysics, Tel Aviv University, Tel Aviv 69978, Israel \\ ${ }^{b}$ now at: Engineering Research Accelerator, Carnegie Mellon University, Pittsburgh, PA 15217, USA
}

Correspondence: Haochi Che (haochiche@tauex.tau.ac.il)

Received: 31 May 2020 - Discussion started: 10 June 2020

Revised: 19 October 2020 - Accepted: 1 November 2020 - Published: 4 January 2021

\begin{abstract}
The south-eastern Atlantic Ocean (SEA) is semipermanently covered by one of the most extensive stratocumulus cloud decks on the planet and experiences about onethird of the global biomass burning emissions from the southern Africa savannah region during the fire season. To get a better understanding of the impact of these biomass burning aerosols on clouds and the radiation balance over the SEA, the latest generation of the UK Earth System Model (UKESM1) is employed. Measurements from the CLARIFY and ORACLES flight campaigns are used to evaluate the model, demonstrating that the model has good skill in reproducing the biomass burning plume. To investigate the underlying mechanisms in detail, the effects of biomass burning aerosols on the clouds are decomposed into radiative effects (via absorption and scattering) and microphysical effects (via perturbation of cloud condensation nuclei - $\mathrm{CCN}-$ and cloud microphysical processes). July-August means are used to characterize aerosols, clouds, and the radiation balance during the fire season. Results show that around $65 \%$ of $\mathrm{CCN}$ at $0.2 \%$ supersaturation in the SEA can be attributed to biomass burning. The absorption effect of biomass burning aerosols is the most significant on clouds and radiation. Near the continent, it increases the supersaturation diagnosed by the activation scheme, while further from the continent it reduces the altitude of the supersaturation. As a result, the cloud droplet number concentration responds with a similar pattern to the absorption effect of biomass burning aerosols. The microphysical effect, however, decreases the supersaturation and increases the cloud droplet concentration over
\end{abstract}

the ocean, although this change is relatively small. The liquid water path is also significantly increased over the SEA (mainly caused by the absorption effect of biomass burning aerosols) when biomass burning aerosols are above the stratocumulus cloud deck. The microphysical pathways lead to a slight increase in the liquid water path over the ocean. These changes in cloud properties indicate the significant role of biomass burning aerosols for clouds in this region. Among the effects of biomass burning aerosols on the radiation balance, the semi-direct radiative effects (rapid adjustments induced by the radiative effects of biomass burning aerosols) have a dominant cooling impact over the SEA, which offset the warming direct radiative effect (radiative forcing from biomass burning aerosol-radiation interactions) and lead to an overall net cooling radiative effect in the SEA. However, the magnitude and the sign of the semi-direct effects are sensitive to the relative location of biomass burning aerosols and clouds, reflecting the critical task of the accurate modelling of the biomass burning plume and clouds in this region.

\section{Introduction}

The south-eastern Atlantic Ocean (SEA) is semipermanently covered by one of the most extensive stratocumulus cloud decks on the planet (Wood, 2012). These clouds reflect a significant amount of solar radiation. Hence, even a moderate change in the cloud deck coverage 
(15\%-20\% increase) or liquid water path $(20 \%-30 \%$ increase) would produce a negative radiative effect that could completely compensate for the radiative forcing of greenhouse gases (Wood, 2012). From July through October, the widespread biomass burning across the savannah region in southern Africa contributes about one-third of the global biomass burning emissions (Roberts et al., 2009; van der Werf et al., 2010). The emitted biomass burning aerosols (BBAs) in southern Africa are transported over the SEA, resulting in different impacts on the underlying stratocumulus deck and radiative balance through multiple interactions (Adebiyi and Zuidema, 2016; Wilcox, 2012; Wood, 2012).

BBAs can warm the lower troposphere and modify the radiation budget as they absorb shortwave radiation. At the top of atmosphere, BBA can exert either a cooling or a warming shortwave direct radiative effect (radiative forcing from BBA-radiation interactions) depending on the underlying layer brightness (e.g. ocean or stratocumulus cloud deck) (Chand et al., 2009; Wilcox, 2012). Despite the fact that intensive studies have been performed (Chand et al., 2009; Lu et al., 2018; Sakaeda et al., 2011; Stier et al., 2013; Wilcox, 2012), there is still no consensus on the magnitude or even the sign of the BBA direct radiative effect over the SEA. This discrepancy is primarily due to the uncertainties in the underlying cloud coverage (Stier et al., 2013) and the BBA spatial distribution; therefore, accurate modelling of the spatial and vertical distribution of the BBA plume and clouds is a critical task in this area.

The interactions between BBA and the underlying cloud deck adds additional complication as BBA can alter the thermodynamic structure of the atmosphere (through rapid adjustments induced by BBA radiative effects, i.e. semi-direct effects) and also serve as additional cloud condensation nuclei $(\mathrm{CCN})$. The former is referred to as the BBA radiative effect on cloud, and the latter is the BBA microphysical effect on cloud. Both effects have a significant impact on the cloud liquid water path (LWP), cloud coverage, and radiation balance (Gordon et al., 2018; Lu et al., 2018; Wilcox, 2010). When the BBA layer is above the cloud deck, its radiative effect can enhance the existing temperature inversion and therefore stability, inhibiting cloud-top entrainment. As a consequence, boundary layer relative humidity is preserved and cloud coverage maintained. This could lead to an increase in LWP, optically thicker clouds, and therefore an additional cooling semi-direct effect - potentially of comparable magnitude to the warming BBA direct radiative effect, resulting in both the sign and the magnitude of the total BBA radiative effect remaining unclear (Deaconu et al., 2019; Sakaeda et al., 2011; Wilcox, 2010, 2012). Previous efforts have mainly focused on the above-cloud BBA radiative effect, as the BBA plume is generally well separated from the underlying cloud deck in experiments (Hobbs, 2002; Wilcox, 2012). However, recent studies found abundant biomass burning influence within the marine boundary layer (MBL) at Ascension Island from in situ observations
(Zuidema et al., 2018) and throughout the SEA from flight measurements (Diamond et al., 2018; Kacarab et al., 2020), confirming the interaction of BBA and clouds. These findings are also supported by the possible BBA effects on changing cloud properties from satellite observations (Costantino and Bréon, 2010, 2013; Painemal et al., 2014). When the BBA plume enters and interacts with clouds, the microphysical effect of BBA is non-negligible, as BBAs can serve as $\mathrm{CCN}$, become activated, and increase the cloud droplet number concentration (CDNC), resulting in optically thicker clouds of higher albedo (Twomey, 1974, 1977). However, some studies have found that when the LWP remains constant, the increased CDNC will increase cloud-top entrainment through the fast evaporation of small droplets at the cloud top, which, in return, can reduce cloud fraction and LWP (Wood, 2012). As a result, the BBA microphysical effect on clouds may be diminished or even cancelled out under some scenarios (Ackerman et al., 2004; Wood, 2007). A recent study found that the BBA number concentration and hygroscopicity played different roles in modulating the CDNC in clean and polluted environments (Kacarab et al., 2020), adding more uncertainty to the BBA microphysical effect. As to the BBA radiative effects, when BBAs enter clouds, they can "burn off" clouds by absorbing shortwave solar radiation and warming the air, with an accompanying increase in saturation vapour pressure (Hansen et al., 1997; Hill et al., 2008; Koch and Del Genio, 2010), which can lead to a decrease in both the cloud LWP and the cloud coverage. Therefore, BBA microphysical and radiative effects can play opposing roles for cloud physical and radiative properties, creating significant uncertainties in the net effective radiative forcing (change in net downward radiative flux at the top of the atmosphere after allowing rapid adjustments) associated with BBA in the SEA area. Hence, it is critical to assess the BBA effects over the SEA during the fire season using a model that can account for all the relevant processes.

The complex interactions between cloud microphysics, radiation, cloud entrainment processes, and, in particular, the small spatial scales involved make the simulation of the stratocumulus clouds deck in the SEA a challenge. Hence, related process studies mainly rely on high-resolution limitedarea models (Gordon et al., 2018; Lu et al., 2018) and idealized large-eddy simulations (Yamaguchi et al., 2015; Zhou et al., 2017). However, ultimately it is important to represent and constrain the related effects in general circulation models (GCMs) widely used to investigate climate responses to anthropogenic perturbations, e.g. by the Intergovernmental Panel on Climate Change (IPCC). In this paper, we use the UK Earth System Model (UKESM1), which is also being used in the recent Coupled Model Intercomparison Project Phase 6, to study the BBA effects on clouds and radiation in the SEA. A detailed description of the model, simulation setup, and the data we used for evaluation is in Sect. 2. The model is evaluated by observations in Sect. 3.1, and BBA effects on clouds are investigated by decomposition into ra- 
diative effects (absorption and scattering) and microphysical effects in Sect. 3.2. The BBA radiative forcing is studied in Sect. 3.3. Section 4 offers conclusions and a discussion.

\section{Method}

The first version of the United Kingdom Earth System Model, UKESM1 (Sellar et al., 2019), is the latest Earth system model developed jointly by the UK's Met Office and the Natural Environment Research Council (NERC). The core of UKESM1 is based on the Hadley Centre Global Environmental Model version 3 (HadGEM3) Global Coupled (GC) climate configuration of the Unified Model (UM) (Hewitt et al., 2011), comprised of the UM atmosphere (Walters et al., 2019), ocean (Storkey et al., 2018), land surface, and sea ice components (Ridley et al., 2018; Walters et al., 2019). Aerosol and its interaction with clouds are represented by the UK Chemistry and Aerosol model (UKCA) (Mulcahy et al., 2020; O'Connor et al., 2014), including the modal aerosol microphysics GLOMAP (Mann et al., 2010), with five interactive log-normal aerosol modes (four soluble modes from nucleation to coarse and one insoluble of Aitken mode) comprised of internally mixed sulfate, sea salt, black carbon, and organic carbon. Mineral dust is represented separately by an externally mixed bin representation (Woodward, 2001).

For BBA emissions, we use the global fire assimilation system (GFAS) version 1 data. GFAS is based on satellite fire radiative power (FRP) products and has been operating in real time under the Monitoring Atmospheric Composition and Change (MACC) project (Kaiser et al., 2012). The GFAS biomass burning emissions are scaled by 2.0 to improve the agreement with observations, as suggested in the model configuration (Johnson et al., 2016), with scale factors commonly used for this emission inventory (Kaiser et al., 2012). For other emissions, the Coupled Model Intercomparison Project Phase 6 (CMIP6) emission data during 2014 are used (Eyring et al., 2016; Gidden et al., 2019).

The model is configured as Global Atmosphere 7.1 (GA7.1), and our simulations are run with a horizontal resolution of N96, i.e. $1.875^{\circ} \times 1.25^{\circ}$, and 85 vertical levels. The sea surface temperatures and sea ice are prescribed with daily reanalysis data (Reynolds et al., 2007). The model simulations are nudged every $6 \mathrm{~h}$ by ERA-Interim horizontal wind fields above $1500 \mathrm{~m}$ (Telford et al., 2008), while the temperature is not nudged to allow the fast adjustments by the BBA, following the recommendations of Zhang et al. (2014). To decompose the BBA effect into radiative and microphysical effects, we performed six simulations from 2016 to 2017: one with present GFAS BBA emissions and the kappa value of organic carbon $\kappa_{\text {org }}$ set to 0.3 (Chang et al., 2010) as the baseline simulation $\left(\mathrm{BB}_{0.3}\right)$, one with the same settings but $\kappa_{\text {org }}$ set to $0\left(\mathrm{BB}_{0}\right)$, two without $\mathrm{BBA}$ emissions and $\kappa_{\text {org }}$ set to 0.3 and $0\left(\right.$ noBB $\left._{0.3}, \operatorname{noBB}_{0}\right)$, and two with $\mathrm{BBA}$ emissions and $\kappa_{\text {org }}$ set to 0.3 and 0 but with the BBA absorption turned off $\left(\right.$ noBB $_{0.3}^{\text {noABS }}$, noBB $\left._{0}^{\text {noABS}}\right)$ (setting the imaginary part of the refractive index to zero). Radiative and microphysical effects of BBA are separated using the method by Lu et al. (2018) and described by the following equations.

$$
\begin{aligned}
& \text { Absorption effect }=\mathrm{BB}_{0}-\mathrm{BB}_{0}^{\text {noABS }} \\
& \begin{aligned}
& \text { Scattering effect }=\mathrm{BB}_{0}^{\text {noABS }}-\text { noBB }_{0} \\
& \text { Total effect }=\mathrm{BB}_{0.3}-\text { noBB } \\
& \text { Microphysical effect }=\text { total effect }- \text { absorption effect } \\
&- \text { scattering effect }
\end{aligned}
\end{aligned}
$$

This method allows us to decompose the effects of BBA, with some limitations due to inherent assumptions and model structures. For example, our model only allows us to switch off the absorption of BBA, not the total radiative effects. This assumes that the cloud adjustment due to BBA scattering is negligible in our experiments (which excludes fast adjustments to corresponding surface flux changes). Also note that the microphysical effect of BBA decomposed from our setting is mainly driven by the variation of $\kappa_{\mathrm{org}}$, and thus the small fraction (around 10\%) of OC from non-biomassburning emissions in this region (Fig. S1) would contribute a small error. Then the BBA radiative effect is further decomposed into direct, indirect (effective radiative forcing from BBA-cloud interactions, defined as rapid adjustments, and the net forcing with these adjustments from BBA-cloud interactions), and semi-direct effects using the method of Ghan et al. (2012) and Gordon et al. (2018). Two years are simulated in the model (2016 and 2017); however, this analysis focuses on July and August for consistency with the flight campaigns. Note that although July and August can be used to represent BBA effects during the African fire season (JulyOctober), this selection will also result in some uncertainties, as the BBA distribution and properties change over the course of the fire season, influenced in part by meteorological shifts, such as the strengthening of the southern African easterly jet (AEJ-S) in September and October, corresponding to a more elevated plume (Adebiyi and Zuidema, 2016).

To evaluate the model performance, we use two flight campaigns that took place in the SEA to compare with the baseline model simulation. One is the ORACLES (Observations of Aerosols above Clouds and their interactions) campaign (Redemann et al., 2020) including three deployments, which were conducted from Namibia in 2016 and from São Tomé in 2017 and 2018 (not used), ranging from the west coast of Africa to Ascension Island. The other is the CLARIFY (Clouds and Aerosol Radiative Impacts and Forcing: Year 2016) campaign (Haywood et al., 2020), which was conducted from Ascension Island in 2017. These flight campaigns were carried out during the biomass burning seasons and have provided an ideal dataset covering both BBA above and interacting with clouds, as previous studies have found that the BBA plume layer generally subsides and meets the gradually deepening marine boundary layer in the vicinity 
of Ascension Island and St. Helena (Adebiyi et al., 2015). However, observations also indicate that the entrainment of BBA into the MBL can be intermittent, can require significant contact time (Diamond et al., 2018), and recirculation patterns can result in clean MBL near Ascension Island. The aerosol extinction from ORACLES $(2016,2017)$ and CLARIFY is used to compare with the model data. For ORACLES, we use the dry aerosol scattering and absorption coefficients from nephelometers and particle soot absorption photometer (PSAP) (Pistone et al., 2019); for CLARIFY, the dry aerosol extinction coefficient was measured by cavity ring-down spectroscopy using the EXSCALABAR instrument (Extinction Scattering and Absorption of Light for AirBorne Aerosol Research; Cotterell et al., 2020; Davies et al., 2018), similar to that reported by Langridge et al. (2011). For the comparison, the extinction data from the observations are calculated at the $550 \mathrm{~nm}$ wavelength by using the Ångström exponent. Then we collocate the 3-hourly variables from the baseline model simulation with the aircraft observations (Watson-Parris et al., 2016, 2019). Two different collocations are performed: one to the 4-D coordinates of the observations (time, longitude, latitude, altitude) and another one with 3-D coordinates (time, longitude, latitude) to provide modelled point and profile data at the location of the observations. The aerosol optical depth (AOD) at $550 \mathrm{~nm}$ from the Moderate Resolution Imaging Spectroradiometer (MODIS) Terra (MOD08_D3, version 4.4) and Aqua (MYD08_D3, Version 4.4) level $3,1^{\circ} \times 1^{\circ}$ resolution, collection 6 daily products is also used to further evaluate the model performance.

\section{Results}

\subsection{Model evaluation}

The spatial and vertical distribution of the BBA plume is critical to aerosol-cloud interactions, as it can significantly impact the sign and magnitude of the BBA effects (Bellouin et al., 2019). To evaluate the performance of the model, the spatial and vertical distributions of the aerosol extinction coefficient from the model are compared with the aircraft observations

The mean spatial distributions of the aerosol extinction coefficient along the flight tracks are illustrated in Fig. 1. Note that the modelled extinction is for ambient aerosols, while the measurement gives dry extinction. Although this intercomparison is widely used in model studies (Shinozuka et al., 2020), it is a potential source of error for modelmeasurement discrepancies, as the extinction coefficient will generally be larger in the model. From Fig. 1, the model generally agrees well with the measurements, and it captures the extinction coefficient peak around $2^{\circ} \mathrm{W}$; however, it also overestimates the extinction around $5^{\circ} \mathrm{W}$. Extinction coefficients are slightly underestimated by the model near the coast of southern Africa and overestimated over the SEA. These errors suggest that the reproduced plume generally agrees well with measurements but is transported too far north and west. These biases might be partly attributable to the coarse model resolution and the use of 3-hourly output, which reduces reliability in the collocation. The comparison of mean July-August AOD from the model and retrievals (at ambient relative humidity) from the MODIS satellite instrument further confirms this bias (Fig. S2), which indicates that the model error may be related to the location and initial altitude of biomass burning emissions. Furthermore, the BBA deposition in the model may be biased low.

The mean vertical distribution of the aerosol extinction coefficient is shown in Fig. 2. The model extinction coefficient profile is collocated to the 3-D (latitude, longitude, time) coordinate of the observation. It can be seen in the figure that the plume is above clouds from the coast to $2^{\circ} \mathrm{W}$, where it shows the extinction peak. From east to west, the plume subsides and comes into contact with the clouds. At $5^{\circ} \mathrm{W}$, the plume is generally inside the clouds, although the actual plume distribution and occurrence of plume-cloud contact at any given time can be more nuanced (Diamond et al., 2018). Thus, the BBAs can interact and modulate cloud properties. This finding is also confirmed by previous studies (Adebiyi et al., 2015; Chand et al., 2009; Deaconu et al., 2019; Gordon et al., 2018). From Fig. 2, the modelled vertical distribution of the BBA plume agrees quite well with the measurements, with the measured peak extinctions generally captured by the model. However, near $11^{\circ} \mathrm{W}$, the modelled extinction coefficient has a slightly lower altitude than the measurement. This may indicate that the altitude of the plume is lower in the model; i.e. the model has less aerosol above cloud or aerosol reaches lower when in clear sky, or it may be the result of comparing simulated extinction at ambient humidity to observations of dry extinction.

This comparison shows that the model has skill in reproducing the BBA plume, although the plume is transported slightly too far west and north and also at a lower altitude towards the western part of the region of interest (westward of $5^{\circ} \mathrm{W}$ ). The bias of the BBA plume location and vertical profile reproduced by the model will contribute to the uncertainty of the BBA microphysical effect over the ocean west of $5^{\circ} \mathrm{W}$ and of the BBA radiative effect. However, these errors are relatively small as the BBA plume is generally well simulated in the model, allowing us to investigate the BBA effect on the underlying and interacting cloud as well as the radiation balance.

\subsection{Biomass burning aerosol impacts on clouds}

BBA can serve as $\mathrm{CCN}$ and further impact the CDNC and cloud optical depth. Meanwhile, it also has a significant impact on the atmospheric thermal structure and therefore the cloud supersaturation, cloud droplet concentration, and cloud albedo. The BBA effects on clouds are decomposed into radiative (absorption and scattering) and microphysical ef- 

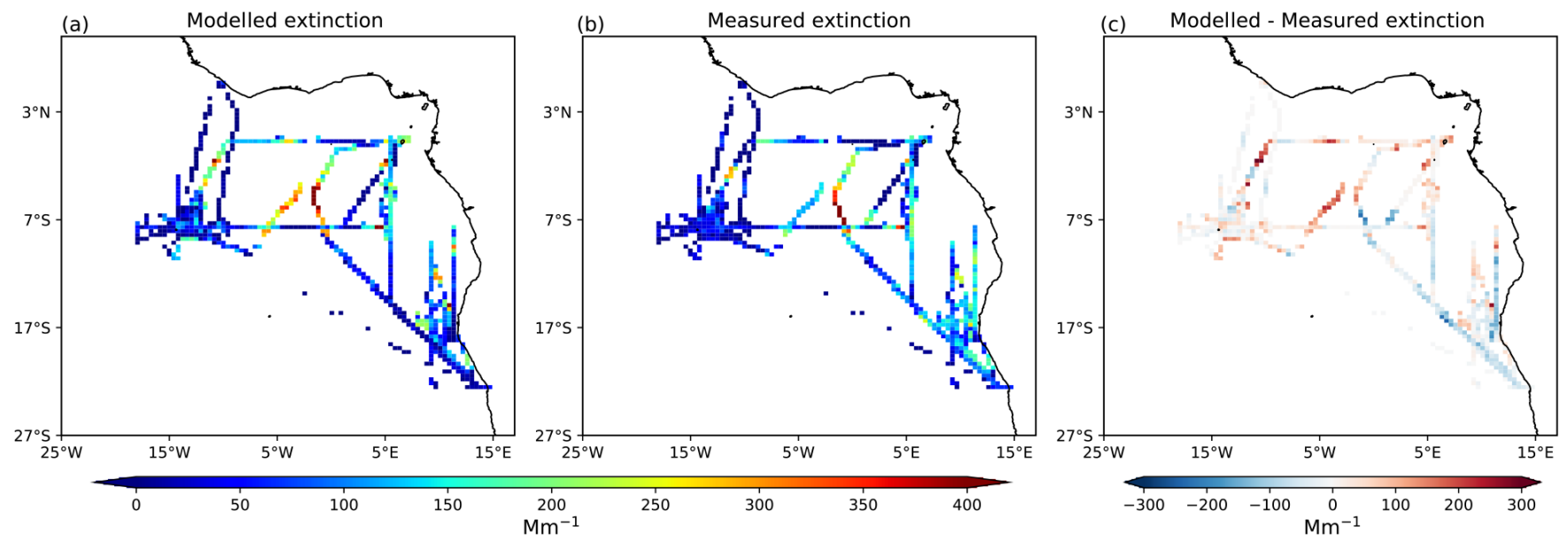

Figure 1. Mean along-track aerosol extinction coefficient $\left(\mathrm{Mm}^{-1}\right)$ from the (a) UKESM1 model collocated to the flight tracks, (b) flight observations, and (c) differences between the model and observations. Note that the model extinction is under ambient conditions, whereas the measured extinction is for dry aerosols with relative humidity below $30 \%$.

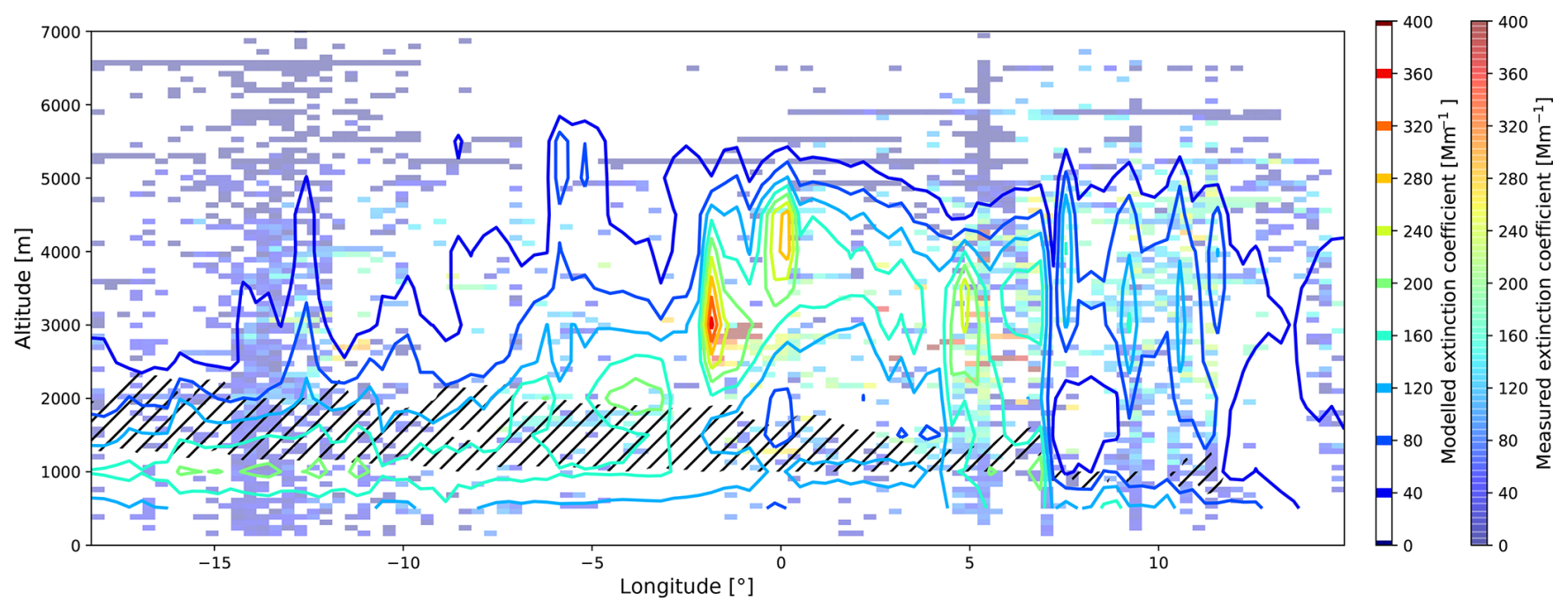

Figure 2. Mean along-flight-track vertical distribution of the aerosol extinction coefficient along longitude. The contour lines show the mean collocated model extinction coefficient profile along with the location of the aircraft. The pixels represent the mean value of the aerosol extinction coefficient from the CLARIFY and ORACLES $(2016,2017)$ campaigns. The hashed lines illustrate the model cloud location by using cloud liquid water content from the model. Note that the modelled extinction is for ambient relative humidity, whereas the measured extinction is for dry aerosols with relative humidity below $30 \%$. The same colour map is applied for measurement and model results to facilitate comparison.

fects (detailed in Sect. 2), and their impact on the clouds is examined in this section. Figure 3 provides the baseline cloud properties from the standard simulation. The domain in Fig. 3a, ranging from $30^{\circ} \mathrm{S}$ to $10^{\circ} \mathrm{N}$ and from $40^{\circ} \mathrm{W}$ to $30^{\circ} \mathrm{E}$, is the focus area of this paper. To get BBA effects on the stratocumulus clouds, a cloud box area is used to represent the stratocumulus cloud deck region (the grey box in Fig. 3a). The mean low cloud fraction is 0.58 in the cloud box region, and its western border reaches the area where the stratocumulus-to-cumulus transition occurs (See Fig. 1 in Gordon et al., 2018), suggesting the dominance of stratocumulus clouds in this area.

\subsubsection{Biomass burning aerosol effects on $\mathrm{CCN}$}

CCN from BBA mainly occur over land and in the eastern part of the SEA. From east to west, a sharp gradient of BBA CCN $0.2 \%$ (CCN at $0.2 \%$ supersaturation) is evident in Fig. 4a, which may be due to the strong aerosol wet and dry removal mechanisms over the SEA, resulting in only BBA with a very small diameter being transported so far away from the continent. Due to the low hygroscopicity of BBA, 

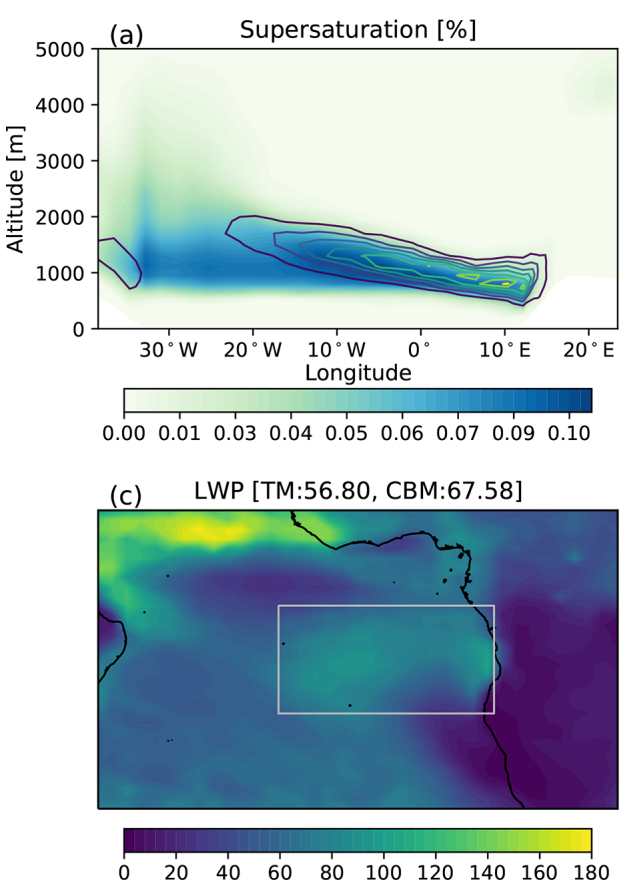

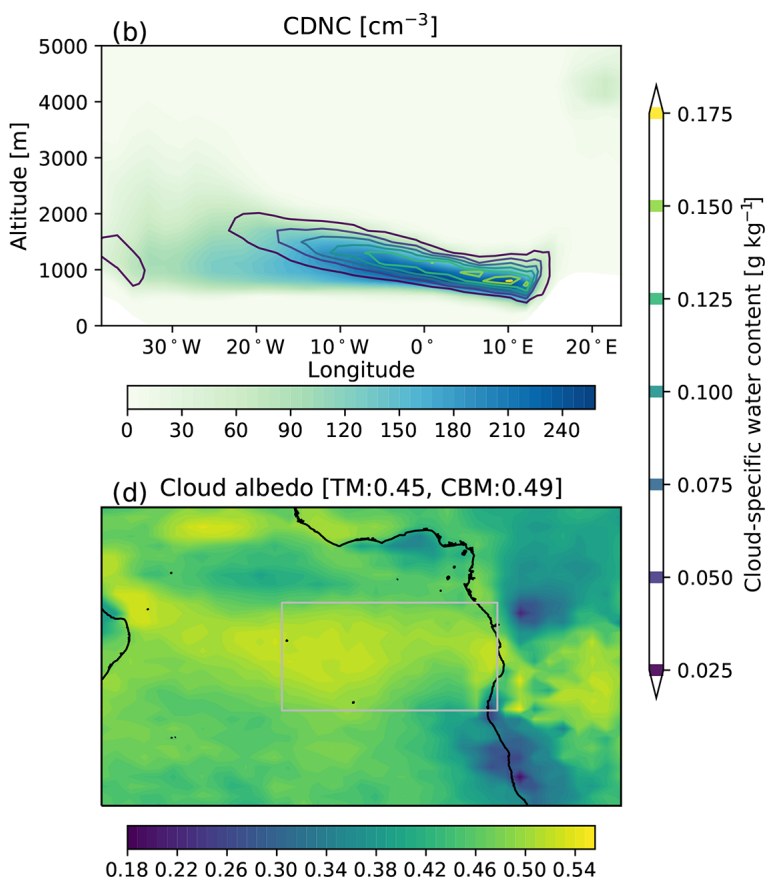

0.180 .220 .260 .300 .340 .380 .420 .460 .500 .54

Figure 3. UKESM1-simulated mean (a) vertical profiles of supersaturation and (b) vertical profiles of cloud droplet number concentration along the latitude of Ascension Island; spatial distribution of (c) cloud liquid water path and (d) cloud albedo from the International Satellite Cloud Climatology Project (ISCCP) simulator. These means are averaged during July and August 2016-2017. The contour lines in (a-b) are the cloud-specific water content. The TM in (c-d) is the total mean of the domain, and the CBM is the mean of the cloud box (the grey box on the map) representing the areas where the average low cloud fraction is above 0.58 .

small-diameter particles (below $0.1 \mu \mathrm{m}$ ) are unable to activate. Furthermore, these fine particles decrease the average hygroscopicity of internally mixed aerosols and can thus reduce the $\mathrm{CCN}$ concentration. The budget of $\mathrm{CCN}_{0.2} \%$ attributed to BBA accounts for $\sim 65 \%$ of total $\mathrm{CCN}_{0.2 \%}$ in the cloud box (grey box) and $\sim 40 \%$ in the whole domain (Fig. S3), indicating that BBA is the dominant source of $\mathrm{CCN}$ in the marine stratocumulus deck area.

The BBA CCN $\mathrm{CN}_{0.2} \%$ profile along the latitude of Ascension Island (Fig. 4b) shows a distinct gradient. With near-source concentrations of $1000 \mathrm{~cm}^{-3}$, the BBA $\mathrm{CCN}_{0.2 \%}$ is transported westward above the clouds and gradually enters the cloud layer from the cloud top, accompanying the increase in the marine boundary layer height and cloud height. These BBAs could impact the cloud droplet number concentration either by acting as $\mathrm{CCN}$ or by evaporation of droplets through shortwave absorption. Although only a small fraction of the BBA associated with $\mathrm{CCN}_{0.2} \%$ has contact with cloud, the in-cloud $\mathrm{CCN}_{0.2} \%$ can still reach up to $\sim 500 \mathrm{~cm}^{-3}$, indicating the significant role of BBA acting as $\mathrm{CCN}$ and the potential impact upon the cloud and radiation balance through modulation of CDNC.

\subsubsection{Biomass burning aerosol effects on cloud droplets}

The July and August averaged profile of BBA radiative and microphysical effects on supersaturation from 2016 to 2017, as diagnosed by the activation scheme, is illustrated in Fig. 5 . BBAs slightly increase the supersaturation near the continent and at low altitude over the SEA, while they decrease the supersaturation at higher altitude. The increased supersaturation mainly results from the BBA absorption effect, as the supersaturation profile is shifted to a lower altitude over the ocean. This supersaturation altitude shift may be related to the change in the MBL height (Fig. S4). When BBA accumulates above the inversion the absorbed shortwave radiation warms the air at the bottom of the inversion layer, strengthening the temperature inversion (Fig. S5) and decreasing the MBL height. This is also supported by a radiosonde research (Adebiyi et al., 2015), which found a shoaling of the boundary layer when absorbing aerosol was above. This effect is especially notable further away from the continent, where the MBL is also higher and sensitive to the temperature profile variations. Near the coast, BBAs are generally above the underlying cloud deck; the absorption aerosols could strengthen the boundary layer inversion (Fig. S4) and thus decrease the dry air entrainment, resulting in increased humidity and hence supersaturation. The increased supersaturation due to BBA absorption can be up to $45 \%$ of the total, indicating the significant role of BBA absorption in cloud droplet formation. The BBA scattering has little impact on supersaturation, with the mean effect around 0 . The microphysical effect of BBA always exerts a negative impact on supersatu- 


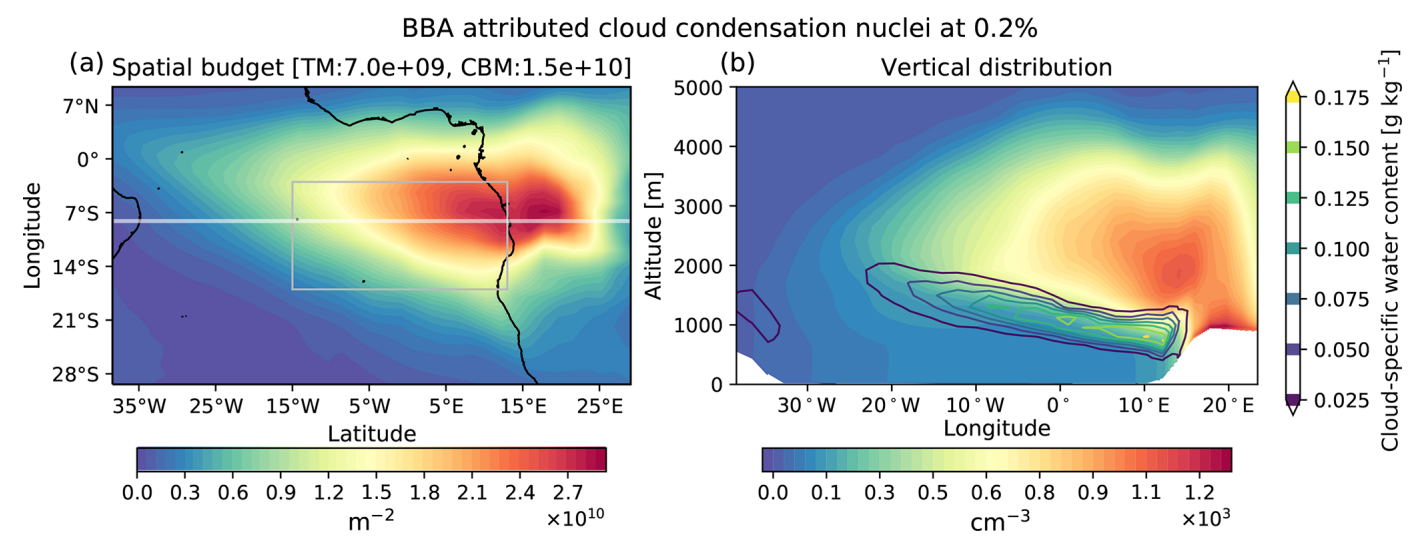

Figure 4. UKESM1-simulated mean cloud condensation nuclei attributed to BBA at $0.2 \%$ supersaturation under standard conditions for temperature and pressure (STP) during July and August 2016-2017 as (a) the vertically integrated burden and (b) profile along the latitude of Ascension Island, $8.1^{\circ} \mathrm{S}$ (the white line in Fig. 3a). The domain in Fig. 3a, ranging from $30^{\circ} \mathrm{S}$ to $10^{\circ} \mathrm{N}$ and from $40^{\circ} \mathrm{W}$ to $30^{\circ} \mathrm{E}$, is the area of interest in this paper. The grey box in the map (cloud box) represents the cloud areas where the averaged low cloud fraction is above 0.58. The TM is the total mean of the domain and the CBM is the mean of the cloud box. The contours in Fig. $3 \mathrm{~b}$ are the cloud-specific water content in the baseline simulation.

ration, as expected from BBA acting as a condensation sink through hygroscopic growth or CCN activation and subsequent droplet growth. However, the decrease in supersaturation due to the BBA microphysical effect is comparatively small, indicating that the ability of BBA to act as CCN in our simulations is limited by its low hygroscopicity. In general, the BBA total effect on supersaturation shares a similar pattern with the absorption effect. However, as the BBA radiative and microphysical effects counterbalance in the lower part of the cloud, the total BBA effect on supersaturation is smaller near the continent and at the cloud base. The increase in supersaturation from the BBA total effect is still quite noticeable.

Before the onset of collision coalescence CDNC is determined by both the $\mathrm{CCN}$ and supersaturation, and the variation of CDNC due to BBA is shown in Fig. 6. As illustrated through the previous analysis, although the radiative properties of BBA are not directly related to the $\mathrm{CCN}$ number concentration, this could still alter supersaturation and hence impact the activation of CCN. The change in CDNC due to the absorption of BBA shows a corresponding response to the effect of BBA on supersaturation, shifting to lower altitude over the ocean, which is expressed as increasing at the cloud base and decreasing at the cloud top over the ocean compared to the baseline simulation. Interestingly, the BBA absorption increases CDNC up to $102 \mathrm{~cm}^{-3}$ near the continent, which is surprisingly high compared to the increased supersaturation. This may partly be because the increased cloud fraction near the continent caused by the stabilizing effect of absorption results in an increase in total CDNC, or the critical supersaturation of ambient aerosols is around the cloud supersaturation, and thus a slight variation of the cloud supersaturation would activate a large quantity of CCN. Unlike the effect of BBA absorption, the increased CDNC due to the microphysical effect is more notable over the sea because only when the BBAs are entrained and interact with the cloud can they be activated as cloud droplets. The scattering effect only slightly increases CDNC when the MBL is deep enough to entrain BBA. However, similarly to the BBA scattering effect on supersaturation, the increased CDNC due to scattering is negligible. In general, the substantial increase in CDNC by BBA can be attributed to the combined effect of absorption and microphysics, whereby the former mainly increases CDNC near the continent and at lower altitude, and the latter increases CDNC above the ocean. Though BBA can contribute up to $56 \%$ of total CDNC in some areas, its average contribution during July-August in the SEA is around $13 \%$, much less than its contribution to the $\mathrm{CCN}_{0.2} \%$ budget fraction. This indicates a contribution of BBAs above the cloud layer unable to activate, although they can serve as $\mathrm{CCN}$ at $0.2 \%$ supersaturation.

\subsubsection{Biomass burning aerosol effects on cloud liquid water}

The simulated changes in LWP in Fig. 7 show a distinct response to BBA over the SEA. Within the cloud box area, the BBA interaction can increase LWP by up to $\sim 34 \%$ of the total (Fig. 3), indicating the critical influence of BBA on the stratocumulus deck. Figure 7 shows that the BBA impacts the LWP mainly through its absorption effect. The increased LWP due to BBA absorption is more significant near the continent than in other areas, which may be because most BBAs are above cloud near the continent. This finding is consistent with the results of large-eddy simulation research (Herbert et al., 2020; Johnson et al., 2004; Yamaguchi et al., 2015; Zhou et al., 2017) indicating that above-cloud BBA can inhibit cloud-top entrainment and increase LWP. When BBA 
Supersaturation along $8.1^{\circ} \mathrm{S}[\%]$
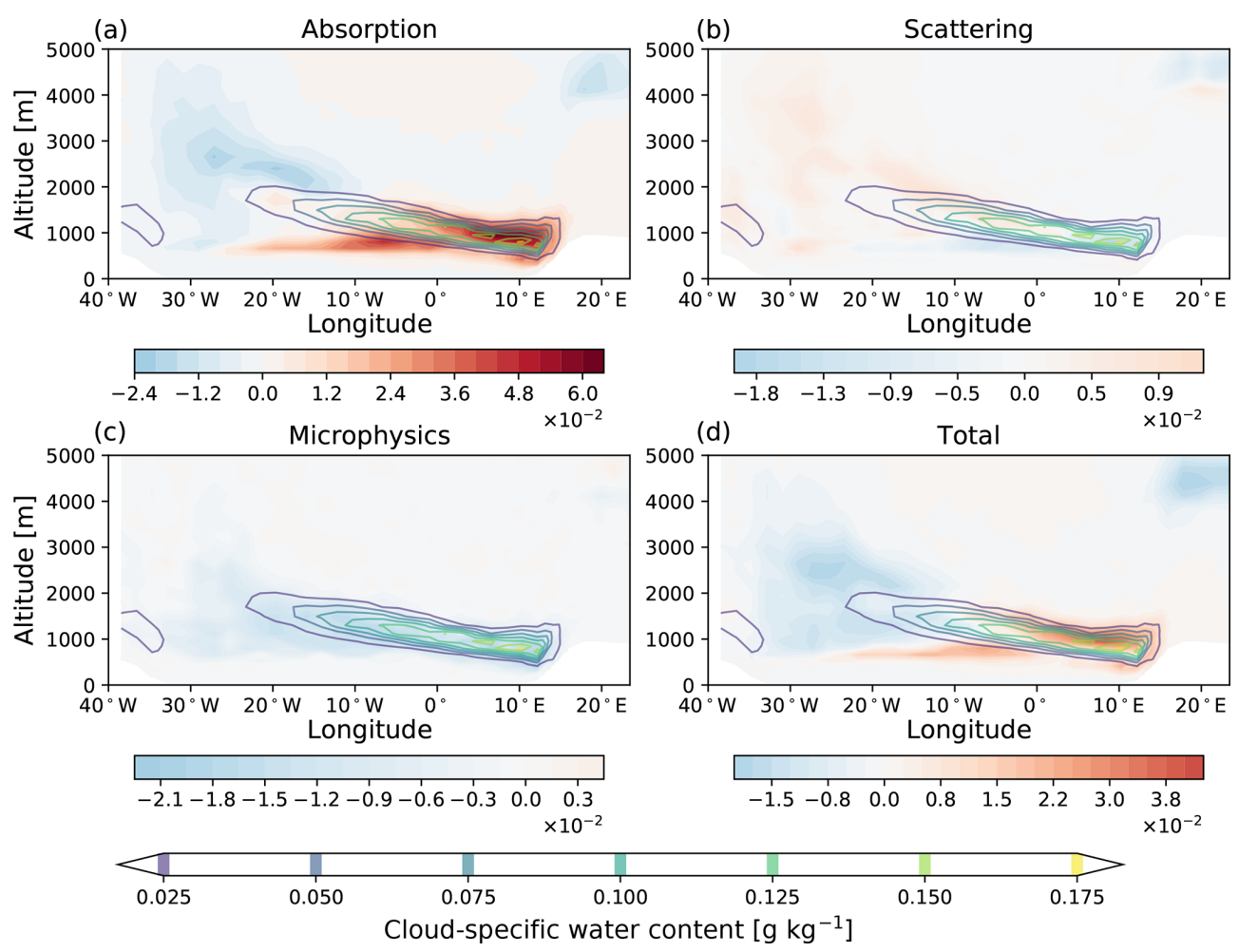

Figure 5. UKESM1-simulated mean vertical profiles of BBA effects on supersaturation along the latitude of Ascension Island (see Fig. 3a) during July and August 2016-2017: (a) absorption, (b) scattering, (c) microphysical, and (d) total. The contour lines are the baseline cloudspecific water content. The same colour map scale is used in each plot to facilitate comparison, but the colour map ranges differ in each plot, corresponding to the maximum and minimum variation of supersaturation in each.

is transported further from the continent, the entrainment of BBA into the cloud layer reduces cloud droplet numbers by lowering the relative humidity through diabatic heating from absorption, which further reduces the increase in LWP and results in a nearly zero or slightly negative effect on LWP. As a result of the different effects of the absorption by BBA and its spatial distribution (more concentrated near the continent), the increased LWP from BBA absorption is mainly located near the continent where BBA and clouds are well separated, indicating the role of BBA in modulating the cloud distribution. The microphysical effect of BBA, which is less clearly distinguishable, generally increases the LWP above the ocean. However, the increase in LWP by the BBA microphysical effect in the cloud box only accounts for $\sim 4 \%$ of the total LWP, far less than the BBA absorption effect. Therefore, the BBA effect on the LWP is mainly due to its absorption characteristics.

\subsubsection{Biomass burning aerosol effects on cloud albedo}

Cloud albedo is crucial in climate, as it is one of the critical parameters in determining the shortwave cloud radiative effect. In the UKESM1, cloud albedo is diagnosed by the International Satellite Cloud Climatology Project (ISCCP) simulator (Bodas-Salcedo et al., 2011), which can minimize the impacts of how clouds are defined in different parameterizations and facilitate model intercomparison. As shown in Fig. 8, BBA generally increases cloud albedo in the cloud box area (total effect), which is consistent with relationships derived from a satellite-based analysis (Deaconu et al., 2019). The cloud albedo increased by BBA accounts for $\sim 8 \%$ of the total in the area where the stratocumulus cloud deck dominates (cloud box area). The effect of BBA on cloud albedo from BBA can be primarily attributed to absorption and the microphysical effect; these two effects together can account for $\sim 90 \%$ of the cloud albedo increase due to BBA in the cloud box area. Unlike the microphysical effect, BBA absorption significantly increases cloud albedo near the continent where most BBAs are above the cloud. The abovecloud BBA can decrease the dry air entrainment, increase the liquid water content due to absorption (see Fig. 7), and lead to an increase in cloud particles and higher cloud albedo. However, when more BBAs are entrained into the MBL, the BBAs decrease the number of cloud droplets through their absorption effect and therefore have a negative impact on the cloud albedo. Therefore, the two different effects of BBA ab- 
Cloud droplet number concentration along $8.1^{\circ} \mathrm{S}\left[\mathrm{cm}^{-3}\right]$
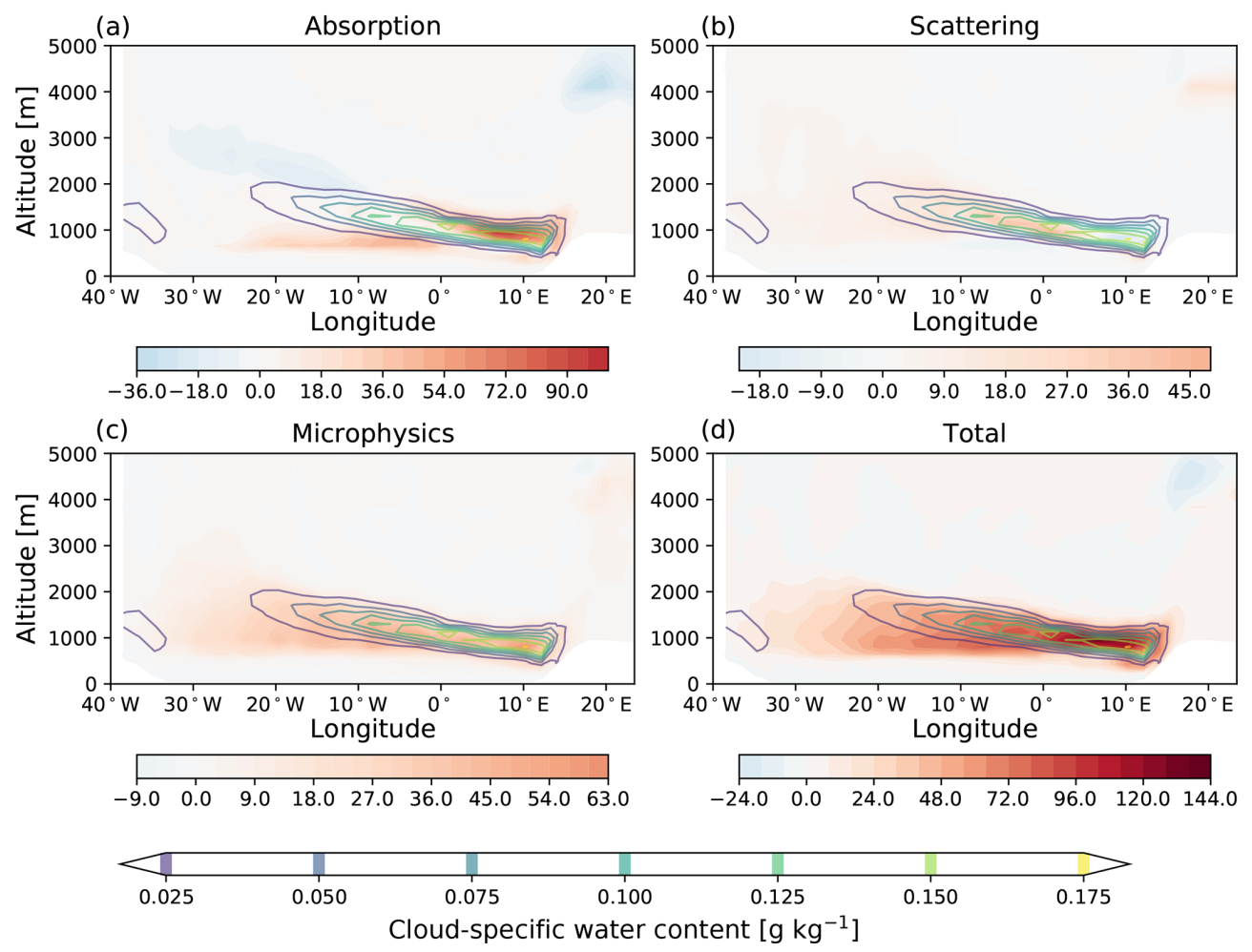

Figure 6. Same as Fig. 5 but for the in-cloud cloud droplet number concentration per cubic centimetre.

sorption - BBA above clouds and inside clouds - counteract each other and result in a slight increase in LWP and a nearly zero impact on the cloud albedo near the western boundary of the cloud box. Note that the LWP and the cloud albedo changes are consistent, although the different colour scale and the non-linear response of cloud albedo to LWP may result in the cloud albedo having less variation than the LWP in the western boundary of the cloud box. The microphysical effect of BBA increases cloud albedo homogenously over the ocean because the increase in CCN provided by BBA increases CDNC. Compared to the effect of BBA absorption, the increased cloud albedo due to a change in $\mathrm{CCN}$ is small, again indicating the significant role of BBA radiative properties.

\subsection{Biomass burning aerosol radiative effect}

The time-averaged BBA effects on the top-of-atmosphere radiation balance are investigated in this section. The simulated direct radiative effect of BBA is generally positive, except in the western areas of the ocean (north-west of Ascension Island) where BBAs have been transported far away from the source. The different sign of the mean direct effect depends on the underlying surface brightness; thus, when BBAs are above clouds, the direct effect shows a warming effect, while under clear sky far away from the continent, it shows a cooling effect. However, the cooling due to the direct effect is negligible, as only a minor proportion of BBA with small particle diameters is transported so far west. The July-August averaged warming effect from the direct effect is large in the cloud box area: up to $\sim 25.5 \mathrm{~W} \mathrm{~m}^{-2}$ near the continent. The indirect radiative effect of BBA shows a similar pattern to the LWP changes due to the microphysical effect of BBA and has a July-August mean cooling effect of $-1.2 \mathrm{~W} \mathrm{~m}^{-2}$ in the cloud box area. In some areas, the indirect effect shows a slight warming effect, which may be caused by the weather noise unconstrained by nudging between different initializations as the cloud fraction and LWP both increase. The magnitude of the indirect effect is strongly related to the $\mathrm{CCN}$; particles with high hygroscopicity could further increase the CDNC. Thus, different settings of OC hygroscopicity would result in differences in the indirect effect. In this paper, we use a kappa value of 0.3 for OC, which may account for some of the uncertainty in the indirect effect.

The BBA semi-direct radiative effects show the most substantial cooling in the cloud box; however, they also have a warming effect in the north-west areas over the sea outside the cloud box. The July-August semi-direct effects can be up to $\sim-52 \mathrm{~W} \mathrm{~m}^{-2}$ near the coast and dominate the total radiative effect in the cloud box area. The cooling of the semi-direct effects is mainly located in the area where the BBAs are above the clouds and results from the significant 


\section{Liquid water path $\left[\mathrm{g} \mathrm{m}^{-2}\right.$ ]}

(a) Absorption [TM:4.0, CBM:25.1]

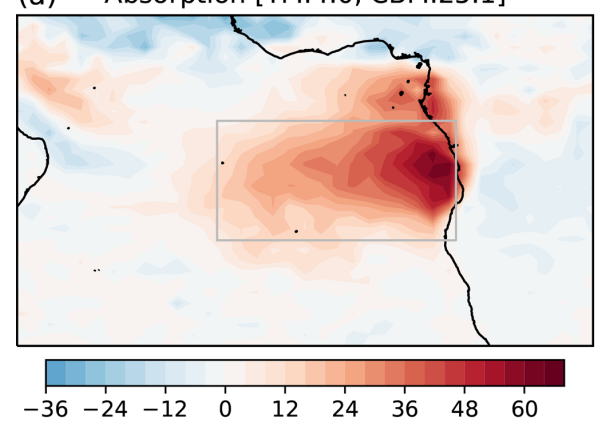

(c) Microphysics [TM:0.7, CBM:2.7]

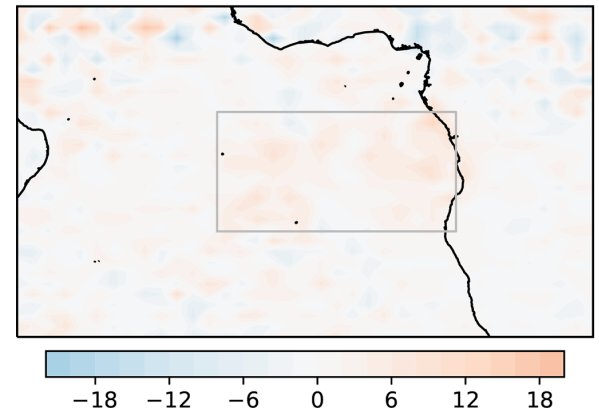

(b) Scattering [TM:-1.1, CBM:-2.2]

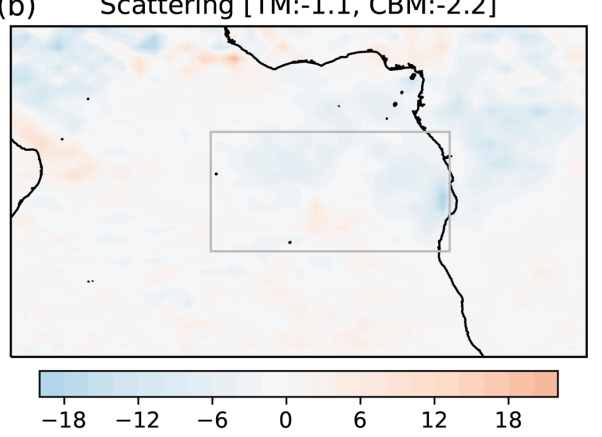

(d)

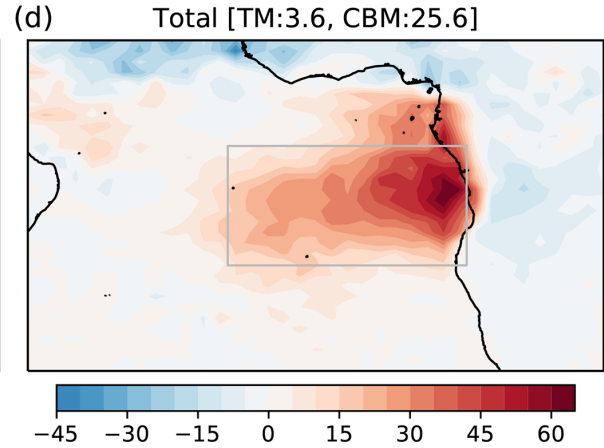

Figure 7. UKESM1-simulated mean spatial distribution of the BBA effects of (a) absorption, (b) scattering, (c) microphysical, and (d) total on the cloud liquid water path during July and August 2016-2017. The domain range is from $30^{\circ} \mathrm{S}$ to $10^{\circ} \mathrm{N}$ and from $40^{\circ} \mathrm{W}$ to $30^{\circ} \mathrm{E}$. The TM is the total mean of the domain and the CBM is the mean of the cloud box (the grey box on the map) representing the areas where the average low cloud fraction is above 0.58 . The same colour scale is used in each plot to facilitate comparison, but the colour map ranges differ in each plot, corresponding to the maximum and minimum variation of LWP in each.

increase in LWP and cloud albedo in that area (due to the stabilizing effect of BBA absorption). The warming effect dominates where the cloud fraction is low and BBAs have already entered the boundary layer, which further reduces the cloud fraction and leads to positive semi-direct effects. Thus, as the dominant effect over the south-eastern Atlantic, the magnitude and the sign of the semi-direct effects are strongly dependent on the relative location of the BBA and the cloud layer. Herbert et al. (2020) studied different layers of the plume with different altitudes and found that the closer the aerosol layer is to the cloud top, the stronger the magnitude of the semi-direct effects. However, in our simulation, the BBA plume is not well separated from the underlying clouds. Thus, when the BBAs are closer to the cloud, some BBA may have entered the cloud layer. As a result, the above-cloud semi-direct effects lead to a top-of-atmosphere (TOA) cooling, whereas in-cloud semi-direct effects lead to a TOA warming.

The total net radiative effect of BBA shows a similar spatial pattern as the semi-direct effects albeit with a smaller magnitude, reflecting the dominant role of semi-direct effects in this region. The total July-August BBA radiative effect over the whole domain is $-0.9 \mathrm{~W} \mathrm{~m}^{-2}$, exerting a net cooling effect in that area. In the cloud box, the JulyAugust averaged BBA total radiative effect can be up to $-30 \mathrm{~W} \mathrm{~m}^{-2}$, with a mean value of $-5.7 \mathrm{~W} \mathrm{~m}^{-2}$. Gordon et al. (2018) have previously estimated the BBA radiative effects near Ascension Island using the same model with a different high-resolution configuration and model version. Comparing the radiative effects in the same domain, the direct and semi-direct effects from their simulations (direct effect: $10.3 \mathrm{~W} \mathrm{~m}^{-2}$; semi-direct effects: $-16.1 \mathrm{~W} \mathrm{~m}^{-2}$ ) are roughly 2 times higher than our results (direct effect: $3.3 \mathrm{~W} \mathrm{~m}^{-2}$; semi-direct effects: $-9.2 \mathrm{~W} \mathrm{~m}^{-2}$ ), as they only sampled the 5 most polluted days. Nevertheless, the indirect effect in their results is $-11.4 \mathrm{~W} \mathrm{~m}^{-2}$, which is disproportionately higher than our simulation $\left(-0.6 \mathrm{~W} \mathrm{~m}^{-2}\right)$. The possible reason behind this discrepancy is that the OC kappa value in their simulation is 0.88 , which is much higher than our setting of 0.3 . Furthermore, the meteorological conditions are different as they only averaged $5 \mathrm{~d}$.

The mean BBA radiative effects in the shortwave and longwave are summarized in Fig. 10. In the cloud box, the semidirect effects are the dominate BBA radiative effect, resulting in a considerable cooling of the total radiative effect over the cloud area. The cooling of semi-direct effects in the cloud 


\section{Cloud albedo}

(a) Absorption [TM:-0.003, CBM:0.024]

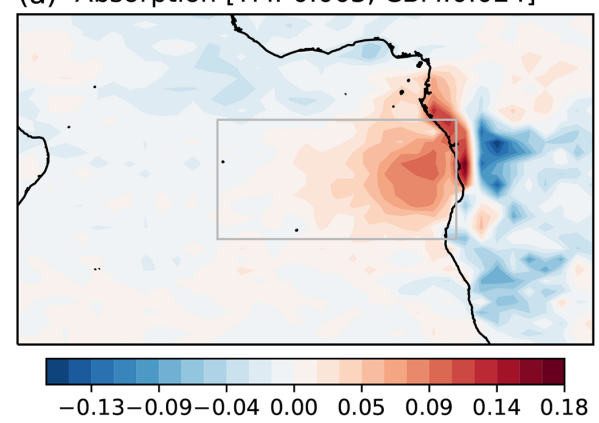

(c) Microphysics [TM:0.005, CBM:0.009]

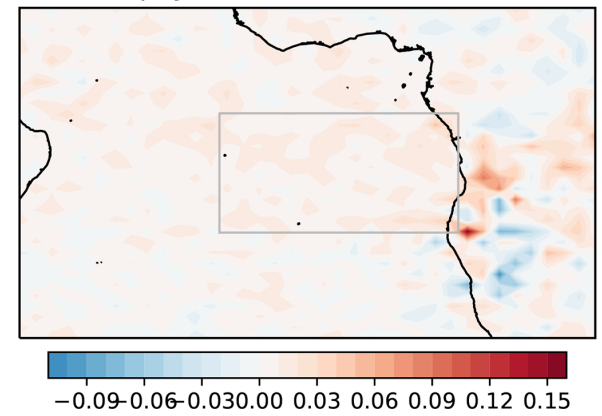

(b) Scattering [TM:0.002, CBM:0.003]

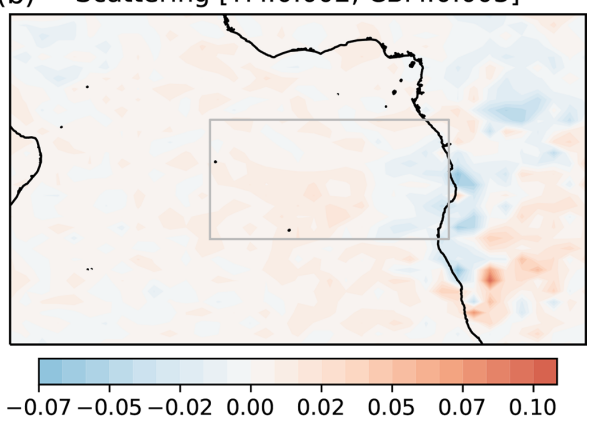

(d) Total [TM:0.003, CBM:0.037]

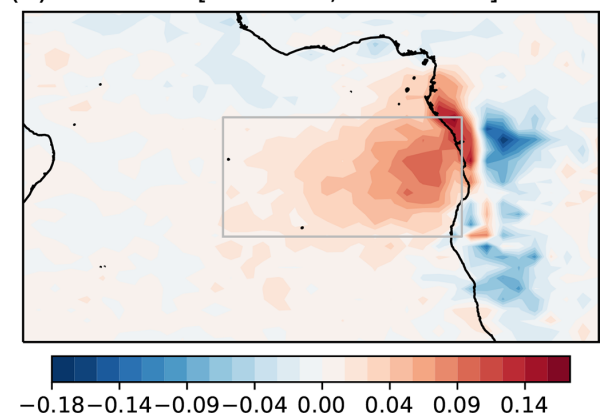

Figure 8. UKESM1 International Satellite Cloud Climatology Project (ISCCP) simulator mean spatial distribution of the BBA effects of (a) absorption, (b) scattering, (c) microphysical, and (d) total on the cloud albedo during July and August 2016-2017. The domain range is from $30^{\circ} \mathrm{S}$ to $10^{\circ} \mathrm{N}$ and from $40^{\circ} \mathrm{W}$ to $30^{\circ} \mathrm{E}$. The TM is the total mean of the domain and the CBM is the mean of the cloud box (the grey box on the map) representing the areas where the average low cloud fraction is above 0.58 . The same colour scale is used in each plot to facilitate comparison, but the colour map ranges differ in each plot, corresponding to the maximum and minimum variation of cloud albedo in each.

box is generally at the shortwave, while at longwave, semidirect effects show a slight warming effect. This may result from the semi-direct enhancement of LWP and cloud cover; therefore, the outgoing longwave radiation at the top of the atmosphere is reduced as it comes from the relatively cool cloud tops rather than the warmer ocean surface, as discussed in Zhou et al. (2017). The direct effect is $7 \mathrm{~W} \mathrm{~m}^{-2}$ in the cloud box area, which partially cancels the cooling of the semi-direct effects. The indirect effect is cooling in this area. However, its magnitude is relatively small, which may result from the limited capability of BBA to act as $\mathrm{CCN}$ due to its low hygroscopicity.

For the regional domain, the BBA semi-direct effects also show a negative cooling effect. However, compared with the cloud box, the mean value of semi-direct effects decreases rapidly when the averaged domain size increases, as it is only about $-1.6 \mathrm{~W} \mathrm{~m}^{-2}$ for the regional domain, i.e. $\sim 13 \%$ of the semi-direct net effects in the cloud box area. Globally, the net semi-direct effects are nearly zero, indicating that the semidirect effects from biomass burning primarily affect the cloud deck over the SEA. The regionally averaged indirect effect is similar to the cloud box mean and slightly lower than the re- gional semi-direct effects, indicating the role of BBA-cloud interactions in this region. In general, BBAs have the most significant radiative effects in the cloud deck area, followed by the South Atlantic Ocean and western Africa (regional domain). The indirect effect is generally the same in these areas and is one of the critical factors in determining the regional radiation balance. The dominant effect in these areas is the cooling effect exerted by the semi-direct radiative effects.

\section{Discussion and conclusion}

The UK Earth System Model (UKESM1) is used to investigate the effects of biomass burning aerosols over the south-eastern Atlantic to provide a better understanding of their radiative and microphysical effects on clouds as well as the radiation balance in this area. The analysis focuses on the biomass burning seasons from July-August for the years 2016 and 2017, which facilitates model evaluation with flight measurements from the ORACLES and CLARIFY campaigns.

Comparison with the flight observations shows that the model generally captures the spatial and vertical distribu- 
BBA radiative effect $\left[\mathrm{W} \mathrm{m}^{-2}\right]$

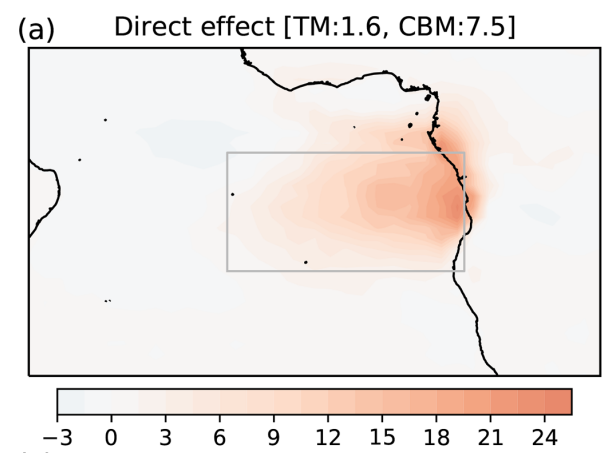

(c) Semi-direct effect [TM:-1.5, CBM:-12.0]
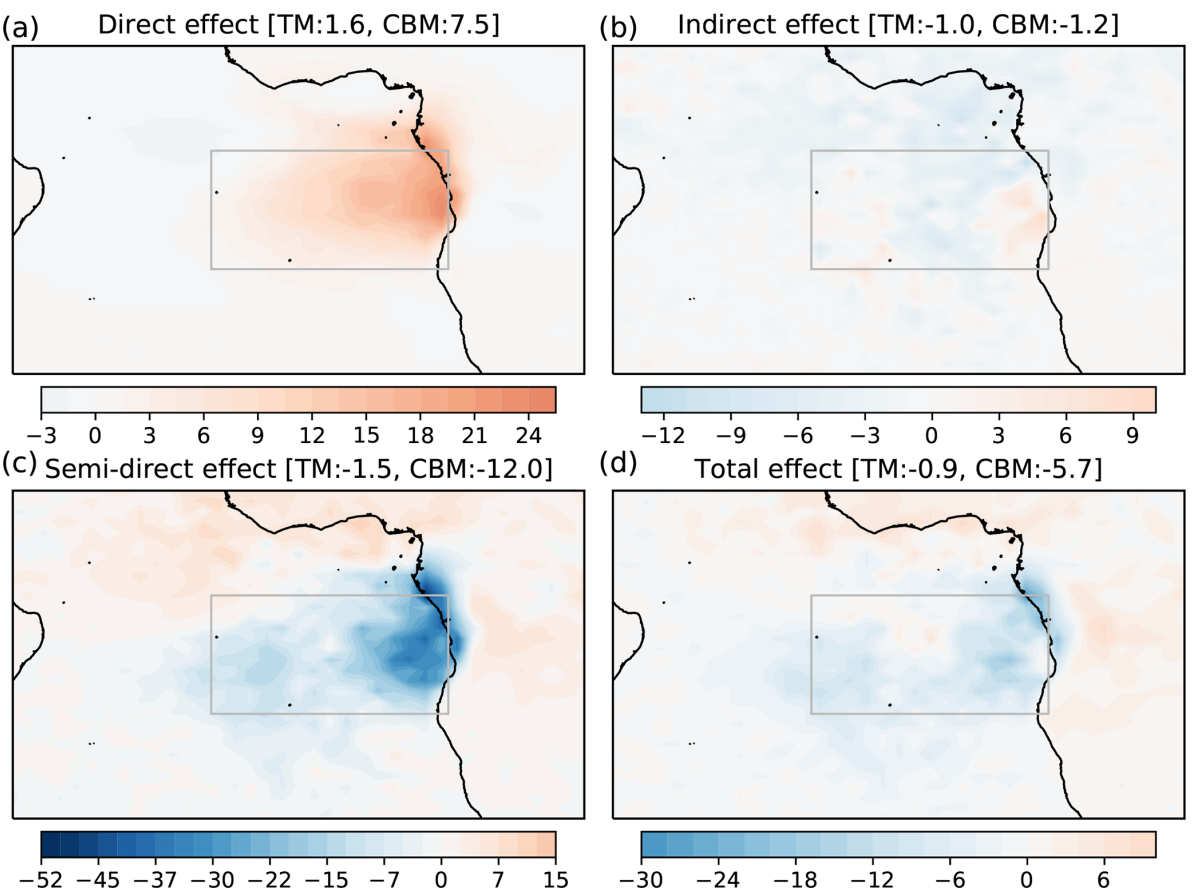

Figure 9. UKESM1 mean net (shortwave + longwave) biomass burning aerosols. (a) Direct, (b) indirect, (c) semi-direct, and (d) total radiative effects during July and August 2016-2017. The same colour map scale is used for each plot, but the colour map ranges differ in each plot, corresponding to the maximum and minimum of the effect in each.

tions of the BBA plume; however, the simulated plume is located too far north-west and at a slightly lower altitude in the model. Although the semi-direct effects and cloud response are sensitive to the relative distance of cloud and the biomass burning plume (Herbert et al., 2020), these errors are relatively small, providing the foundation for our investigation of the BBA effect on clouds and the radiation balance in this region.

BBA-associated CCN are emitted from the land and then transported westward above the cloud. With the increase in the marine boundary layer height and reduction of the plume height, BBAs enter the cloud layer from the top. The budget of $\mathrm{CCN}_{0.2} \%$ attributable to BBA can account for $\sim 65 \%$ of the total $\mathrm{CCN}_{0.2 \%}$ in the cloud box area, indicating that BBAs are the primary source of $\mathrm{CCN}$ for the marine stratocumulus deck.

The effects of BBA on clouds are separated into radiative effects (including the effects from absorption and scattering) and the microphysical effect. The impact of BBA on in-cloud supersaturation is mainly due to its absorption. When BBAs accumulate above the inversion, the absorbed shortwave radiation warms the air at the bottom of the inversion layer, strengthening the temperature inversion and decreasing the marine boundary layer height. As a consequence, the supersaturation shifts to a lower altitude above the ocean. Near the coast, the above-cloud BBA strengthens the temperature in- version, which results in the weakening of entrainment across the inversion layer, as buoyant parcels of air in the MBL require more energy in order to push through the strengthened temperature inversion (Herbert et al., 2020). Therefore, the relative humidity increases, as does the supersaturation. As a consequence, the BBA absorption effect shows a corresponding response to the supersaturation, with increases at low altitudes (cloud bottom in the baseline simulation), decreases at high altitudes (cloud top from baseline) over the ocean further offshore, and general increases near the continent. The microphysical effect decreases the supersaturation, as BBA can act as $\mathrm{CCN}$ and allow additional water vapour to condense; however, this decrease is comparatively small. The CDNC over SEA is increased, especially further offshore, due to the BBA microphysical effect compensating for the decreased CDNC at higher altitude from the absorption effect. In general, BBA absorption and microphysical effects both contribute to the increase in CDNC, although the former is mainly through affecting the supersaturation, while the latter is through increasing $\mathrm{CCN}$.

The BBA absorption effect increases LWP significantly when BBAs are located above the stratocumulus deck, as the stabilization from absorption can inhibit cloud-top entrainment. When BBA enters the cloud layer, it can decrease the amount of condensable liquid water and so decrease the LWP. As a result, the variation of LWP due to the absorp- 
Biomass burning aerosol effect on radiation
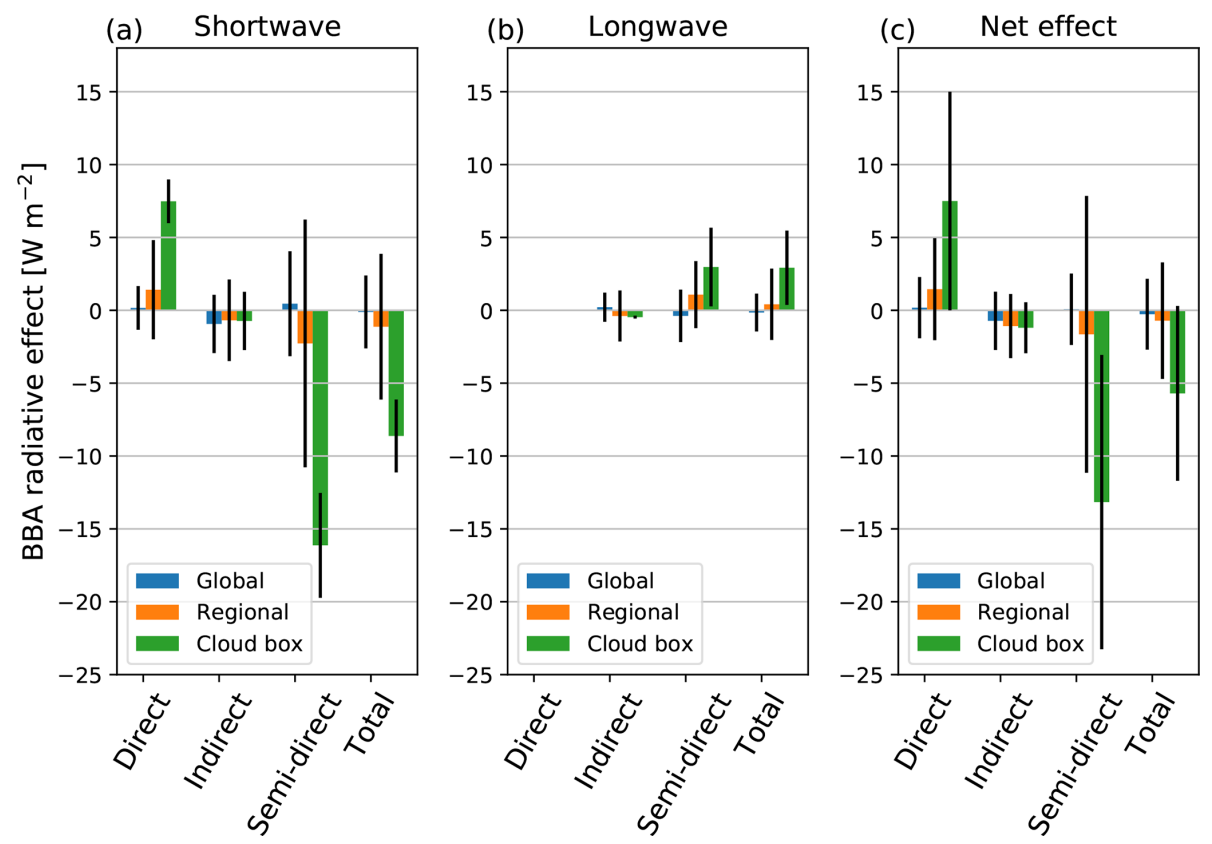

Figure 10. Bar chart of UKESM1 mean BBA radiative effect during July and August 2016-2017. The BBA radiative effect at the (a) shortwave and (b) longwave as well as the (c) net effect are presented in separate plots. Blue represents the global mean; orange is the domain mean, and green is the cloud box mean. The error bars represent standard errors.

tion effect is nearly zero or slightly negative when far away from the continent. The microphysical effect also contributes to the increase in LWP; however, this increase is small compared to the absorption effect. Therefore, the LWP response to BBA is dominated by the effect of absorption, showing a substantial increase over the south-eastern Atlantic. The variation of cloud albedo due to BBA shows a similar pattern as the LWP.

The dominance of the effect of absorption on cloud properties is reflected in the effect on the top-of-atmosphere radiation balance. When BBAs are above the stratocumulus deck, semi-direct effects contribute most to the overall cooling, while they also exert a warming effect in the north-west areas over the sea. The magnitude and the sign of the semidirect effects are dependent on the relative location of BBA and clouds, as BBAs can either increase the underlying cloud LWP or decrease the surrounding droplet numbers depending on whether the BBAs are above or inside the cloud. The direct radiative effect is generally positive and shows a strong warming when BBAs are above the stratocumulus deck (with a July-August average of $7.5 \mathrm{~W} \mathrm{~m}^{-2}$ ), as the surface albedo of the underlying clouds is fairly high. However, for the total net $\mathrm{BBA}$ radiative effect the positive direct radiative effect is more than compensated for by the semi-direct effects, resulting in an overall cooling effect over the SEA (with a JulyAugust average of $-0.9 \mathrm{~W} \mathrm{~m}^{-2}$ ). In addition to the semidirect effects, the indirect radiative effect is also negative, showing a cooling in this area. The indirect effect mainly results from the response of LWP to the BBA microphysical effect, as they share a similar spatial pattern. When comparing the BBA radiative effects at different scales, we find that semi-direct effects from biomass burning play a significant role over the south-eastern Atlantic stratocumulus deck, while they have little impact on the global mean.

Data availability. The original simulation data are available from the JASMIN facility upon request. There are also processed model data, which can be downloaded from https://data.mendeley.com/ datasets/xdxh8stc48/3 (Che, 2020). Data from the CLARIFY aircraft campaign are available on the CEDA repository at http:// archive.ceda.ac.uk/ (Facility for Airborne Atmospheric Measurements, Natural Environment Research Council, and Met Office, 2020). Data from ORACLES aircraft campaigns are available on the repository at https://espo.nasa.gov/oracles/archive/browse/oracles (ORACLES Science Team, 2020a, b).

Supplement. The supplement related to this article is available online at: https://doi.org/10.5194/acp-21-17-2021-supplement.

Author contributions. PS and HC developed the concepts and ideas for the direction of the paper. HC and HG set up the model. HC carried out and analysed the model simulation. DWP and HC performed the model validation. LD, DWP, HG, HC, and PS con- 
tributed to the analysis of the results. HC wrote the paper with input and comments from all other authors.

Competing interests. The authors declare that they have no conflict of interest.

Special issue statement. This article is part of the special issue "New observations and related modelling studies of the aerosolcloud-climate system in the Southeast Atlantic and southern Africa regions (ACP/AMT inter-journal SI)". It is not associated with a conference.

Acknowledgements. We sincerely acknowledge Kate Szpek from the Met Office CLARIFY team and Steven Howell from the NASA ORACLES team for providing aerosol scattering and absorption data, as well as all CLARIFY and ORACLES science teams for data support. We also thank Luke Abraham and William Ingram for the help with the model, Ben Johnson for the help with setting up biomass burning emissions, and William Jones for proofreading the paper. We acknowledge the use of the Monsoon2 system, a collaborative facility supplied under the Joint Weather and Climate Research Programme, a strategic partnership between the UK Met Office and the Natural Environment Research Council (NERC). We also used the JASMIN facility (https://www.jasmin.ac.uk/, last access: 21 December 2020) via the Centre for Environmental Data Analysis, funded by NERC and the UK Space Agency and delivered by the Science and Technology Facilities Council.

Financial support. This research has been supported by the Natural Environment Research Council CLARIFY project (grant no. NE/L01355X/1) and European Research Council constRaining the EffeCts of Aerosols on Precipitation (RECAP) (grant no. 724602).

Review statement. This paper was edited by Frank Eckardt and reviewed by Michael Diamond and one anonymous referee.

\section{References}

Ackerman, A. S., Kirkpatrick, M. P., Stevens, D. E., and Toon, O. B.: The impact of humidity above stratiform clouds on indirect aerosol climate forcing, Nature, 432, 1014, https://doi.org/10.1038/nature03174, 2004.

Adebiyi, A. A. and Zuidema, P.: The role of the southern African easterly jet in modifying the southeast Atlantic aerosol and cloud environments, Q. J. Roy. Meteorol. Soc., 142, 1574-1589, https://doi.org/10.1002/qj.2765, 2016.

Adebiyi, A. A., Zuidema, P., and Abel, S. J.: The Convolution of Dynamics and Moisture with the Presence of Shortwave Absorbing Aerosols over the Southeast Atlantic, J. Climate, 28, 19972024, https://doi.org/10.1175/JCLI-D-14-00352.1, 2015.

Bellouin, N., Quaas, J., Gryspeerdt, E., Kinne, S., Stier, P., WatsonParris, D., Boucher, O., Carslaw, K. S., Christensen, M., Daniau,
A.-L., Dufresne, J.-L., Feingold, G., Fiedler, S., Forster, P., Gettelman, A., Haywood, J. M., Lohmann, U., Malavelle, F., Mauritsen, T., McCoy, D. T., Myhre, G., Mülmenstädt, J., Neubauer, D., Possner, A., Rugenstein, M., Sato, Y., Schulz, M., Schwartz, S. E., Sourdeval, O., Storelvmo, T., Toll, V., Winker, D., and Stevens, B.: Bounding global aerosol radiative forcing of climate change, Reviews of Geophysics, 58, e2019RG000660, 2019.

Bodas-Salcedo, A., Webb, M. J., Bony, S., Chepfer, H., Dufresne, J.-L., Klein, S. A., Zhang, Y., Marchand, R., Haynes, J. M., Pincus, R., and John, V. O.: COSP: Satellite simulation software for model assessment, B. Am. Meteor. Soc., 92, 1023-1043, https://doi.org/10.1175/2011BAMS2856.1, 2011.

Chand, D., Wood, R., Anderson, T. L., Satheesh, S. K., and Charlson, R. J.: Satellite-derived direct radiative effect of aerosols dependent on cloud cover, Nat. Geosci., 2, 181-184, https://doi.org/10.1038/ngeo437, 2009.

Chang, R. Y.-W., Slowik, J. G., Shantz, N. C., Vlasenko, A., Liggio, J., Sjostedt, S. J., Leaitch, W. R., and Abbatt, J. P. D.: The hygroscopicity parameter $(\kappa)$ of ambient organic aerosol at a field site subject to biogenic and anthropogenic influences: relationship to degree of aerosol oxidation, Atmos. Chem. Phys., 10, 5047-5064, https://doi.org/10.5194/acp-10-5047-2010, 2010.

Che, H.: Cloud adjustments dominate the overall negative aerosol radiative effects of biomass burning aerosols in UKESM1 climate model simulations over the south-eastern Atlantic, Mendeley Data, V3, https://doi.org/10.17632/xdxh8stc48.3, 2020.

Costantino, L. and Bréon, F.-M.: Analysis of aerosol-cloud interaction from multi-sensor satellite observations, Geophys. Res. Lett., 37, L11801, https://doi.org/10.1029/2009GL041828, 2010.

Costantino, L. and Bréon, F.-M.: Aerosol indirect effect on warm clouds over South-East Atlantic, from co-located MODIS and CALIPSO observations, Atmos. Chem. Phys., 13, 69-88, https://doi.org/10.5194/acp-13-69-2013, 2013

Cotterell, M. I., Szpek, K., Haywood, J. M., and Langridge, J. M.: Sensitivity and accuracy of refractive index retrievals from measured extinction and absorption cross sections for mobility-selected internally mixed light absorbing aerosols, Aerosol Sci. Tech., 54, 1034-1057, https://doi.org/10.1080/02786826.2020.1757034, 2020.

Davies, N. W., Cotterell, M. I., Fox, C., Szpek, K., Haywood, J. M., and Langridge, J. M.: On the accuracy of aerosol photoacoustic spectrometer calibrations using absorption by ozone, Atmos. Meas. Tech., 11, 2313-2324, https://doi.org/10.5194/amt11-2313-2018, 2018.

Deaconu, L. T., Ferlay, N., Waquet, F., Peers, F., Thieuleux, F., and Goloub, P.: Satellite inference of water vapour and abovecloud aerosol combined effect on radiative budget and cloudtop processes in the southeastern Atlantic Ocean, Atmos. Chem. Phys., 19, 11613-11634, https://doi.org/10.5194/acp-19-116132019, 2019.

Diamond, M. S., Dobracki, A., Freitag, S., Small Griswold, J. D., Heikkila, A., Howell, S. G., Kacarab, M. E., Podolske, J. R., Saide, P. E., and Wood, R.: Time-dependent entrainment of smoke presents an observational challenge for assessing aerosolcloud interactions over the southeast Atlantic Ocean, Atmos. Chem. Phys., 18, 14623-14636, https://doi.org/10.5194/acp-1814623-2018, 2018.

Eyring, V., Bony, S., Meehl, G. A., Senior, C. A., Stevens, B., Stouffer, R. J., and Taylor, K. E.: Overview of the Coupled 
Model Intercomparison Project Phase 6 (CMIP6) experimental design and organization, Geosci. Model Dev., 9, 1937-1958, https://doi.org/10.5194/gmd-9-1937-2016, 2016.

Facility for Airborne Atmospheric Measurements, Natural Environment Research Council, and Met Office: CLARIFY: in-situ airborne observations by the FAAM BAE-146 aircraft, Centre for Environmental Data Analysis, available at: http://catalogue. ceda.ac.uk/uuid/38ab7089781a4560b067dd6c20af3769 last access: 21 December 2020.

Ghan, S. J., Liu, X., Easter, R. C., Zaveri, R., Rasch, P. J., Yoon, J.H., and Eaton, B.: Toward a Minimal Representation of Aerosols in Climate Models: Comparative Decomposition of Aerosol Direct, Semidirect, and Indirect Radiative Forcing, J. Climate, 25, 6461-6476, https://doi.org/10.1175/JCLI-D-11-00650.1, 2012.

Gidden, M. J., Riahi, K., Smith, S. J., Fujimori, S., Luderer, G., Kriegler, E., van Vuuren, D. P., van den Berg, M., Feng, L., Klein, D., Calvin, K., Doelman, J. C., Frank, S., Fricko, O., Harmsen, M., Hasegawa, T., Havlik, P., Hilaire, J., Hoesly, R., Horing, J., Popp, A., Stehfest, E., and Takahashi, K.: Global emissions pathways under different socioeconomic scenarios for use in CMIP6: a dataset of harmonized emissions trajectories through the end of the century, Geosci. Model Dev., 12, 14431475, https://doi.org/10.5194/gmd-12-1443-2019, 2019.

Gordon, H., Field, P. R., Abel, S. J., Dalvi, M., Grosvenor, D. P., Hill, A. A., Johnson, B. T., Miltenberger, A. K., Yoshioka, M., and Carslaw, K. S.: Large simulated radiative effects of smoke in the south-east Atlantic, Atmos. Chem. Phys., 18, 15261-15289, https://doi.org/10.5194/acp-18-15261-2018, 2018.

Hansen, J., Sato, M., and Ruedy, R.: Radiative forcing and climate response, J. Geophys. Res.-Atmos., 102, 6831-6864, 1997.

Haywood, J. M., Abel, S. J., Barrett, P. A., Bellouin, N., Blyth, A., Bower, K. N., Brooks, M., Carslaw, K., Che, H., Coe, H., Cotterell, M. I., Crawford, I., Cui, Z., Davies, N., Dingley, B., Field, P., Formenti, P., Gordon, H., de Graaf, M., Herbert, R., Johnson, B., Jones, A. C., Langridge, J. M., Malavelle, F., Partridge, D. G., Peers, F., Redemann, J., Stier, P., Szpek, K., Taylor, J. W., Watson-Parris, D., Wood, R., Wu, H., and Zuidema, P.: Overview: The CLoud-Aerosol-Radiation Interaction and Forcing: Year-2017 (CLARIFY-2017) measurement campaign, Atmos. Chem. Phys. Discuss., https://doi.org/10.5194/acp-2020729, in review, 2020.

Herbert, R. J., Bellouin, N., Highwood, E. J., and Hill, A. A.: Diurnal cycle of the semi-direct effect from a persistent absorbing aerosol layer over marine stratocumulus in large-eddy simulations, Atmos. Chem. Phys., 20, 1317-1340, https://doi.org/10.5194/acp-20-1317-2020, 2020.

Hewitt, H. T., Copsey, D., Culverwell, I. D., Harris, C. M., Hill, R. S. R., Keen, A. B., McLaren, A. J., and Hunke, E. C.: Design and implementation of the infrastructure of HadGEM3: the next-generation Met Office climate modelling system, Geosci. Model Dev., 4, 223-253, https://doi.org/10.5194/gmd-4-2232011, 2011.

Hill, A. A., Dobbie, S., and Yin, Y.: The impact of aerosols on nonprecipitating marine stratocumulus. I: Model description and prediction of the indirect effect, Q. J. Roy. Meteor. Soc., 134, 11431154, https://doi.org/10.1002/qj.278, 2008.

Hobbs, P. V.: Clean air slots amid atmospheric pollution, Nature, 415, 861, https://doi.org/10.1038/415861a, 2002.
Johnson, B. T., Shine, K. P., and Forster, P. M.: The semidirect aerosol effect: Impact of absorbing aerosols on marine stratocumulus, Q. J. Roy. Meteor. Soc., 130, 1407-1422, https://doi.org/10.1256/qj.03.61, 2004.

Johnson, B. T., Haywood, J. M., Langridge, J. M., Darbyshire, E., Morgan, W. T., Szpek, K., Brooke, J. K., Marenco, F., Coe, H., Artaxo, P., Longo, K. M., Mulcahy, J. P., Mann, G. W., Dalvi, M., and Bellouin, N.: Evaluation of biomass burning aerosols in the HadGEM3 climate model with observations from the SAMBBA field campaign, Atmos. Chem. Phys., 16, 1465714685, https://doi.org/10.5194/acp-16-14657-2016, 2016.

Kacarab, M., Thornhill, K. L., Dobracki, A., Howell, S. G., O’Brien, J. R., Freitag, S., Poellot, M. R., Wood, R., Zuidema, P., Redemann, J., and Nenes, A.: Biomass burning aerosol as a modulator of the droplet number in the southeast Atlantic region, Atmos. Chem. Phys., 20, 3029-3040, https://doi.org/10.5194/acp20-3029-2020, 2020.

Kaiser, J. W., Heil, A., Andreae, M. O., Benedetti, A., Chubarova, N., Jones, L., Morcrette, J.-J., Razinger, M., Schultz, M. G., Suttie, M., and van der Werf, G. R.: Biomass burning emissions estimated with a global fire assimilation system based on observed fire radiative power, Biogeosciences, 9, 527-554, https://doi.org/10.5194/bg-9-527-2012, 2012.

Koch, D. and Del Genio, A. D.: Black carbon semi-direct effects on cloud cover: review and synthesis, Atmos. Chem. Phys., 10, 7685-7696, https://doi.org/10.5194/acp-10-7685-2010, 2010.

Langridge, J. M., Richardson, M. S., Lack, D., Law, D., and Murphy, D. M.: Aircraft Instrument for Comprehensive Characterization of Aerosol Optical Properties, Part I: Wavelength-Dependent Optical Extinction and Its Relative Humidity Dependence Measured Using Cavity Ringdown Spectroscopy, Aerosol Sci. Tech., 45, 1305-1318, https://doi.org/10.1080/02786826.2011.592745, 2011.

Lu, Z., Liu, X., Zhang, Z., Zhao, C., Meyer, K., Rajapakshe, C., Wu, C., Yang, Z., and Penner, J. E.: Biomass smoke from southern Africa can significantly enhance the brightness of stratocumulus over the southeastern Atlantic Ocean, P. Natl. Acad. Sci. USA, 115, 2924-2929, https://doi.org/10.1073/pnas.1713703115, 2018.

Mann, G. W., Carslaw, K. S., Spracklen, D. V., Ridley, D. A., Manktelow, P. T., Chipperfield, M. P., Pickering, S. J., and Johnson, C. E.: Description and evaluation of GLOMAP-mode: a modal global aerosol microphysics model for the UKCA composition-climate model, Geosci. Model Dev., 3, 519-551, https://doi.org/10.5194/gmd-3-519-2010, 2010.

Mulcahy, J. P., Johnson, C., Jones, C. G., Povey, A. C., Scott, C. E., Sellar, A., Turnock, S. T., Woodhouse, M. T., Abraham, N. L., Andrews, M. B., Bellouin, N., Browse, J., Carslaw, K. S., Dalvi, M., Folberth, G. A., Glover, M., Grosvenor, D. P., Hardacre, C., Hill, R., Johnson, B., Jones, A., Kipling, Z., Mann, G., Mollard, J., O'Connor, F. M., Palmiéri, J., Reddington, C., Rumbold, S. T., Richardson, M., Schutgens, N. A. J., Stier, P., Stringer, M., Tang, Y., Walton, J., Woodward, S., and Yool, A.: Description and evaluation of aerosol in UKESM1 and HadGEM3-GC3.1 CMIP6 historical simulations, Geosci. Model Dev., 13, 63836423, https://doi.org/10.5194/gmd-13-6383-2020, 2020.

O'Connor, F. M., Johnson, C. E., Morgenstern, O., Abraham, N. L., Braesicke, P., Dalvi, M., Folberth, G. A., Sanderson, M. G., Telford, P. J., Voulgarakis, A., Young, P. J., Zeng, G., Collins, 
W. J., and Pyle, J. A.: Evaluation of the new UKCA climatecomposition model - Part 2: The Troposphere, Geosci. Model Dev., 7, 41-91, https://doi.org/10.5194/gmd-7-41-2014, 2014.

ORACLES Science Team: Suite of Aerosol, Cloud, and Related Data Acquired Aboard P3 During ORACLES 2016, Version 2, NASA Ames Earth Science Project Office, https://doi.org/10.5067/Suborbital/ORACLES/P3/2016_V2, 2020a.

ORACLES Science Team: Suite of Aerosol, Cloud, and Related Data Acquired Aboard P3 During ORACLES 2017, Version 2, NASA Ames Earth Science Project Office, https://doi.org/10.5067/Suborbital/ORACLES/P3/2017_V2, 2020 b.

Painemal, D., Kato, S., and Minnis, P.: Boundary layer regulation in the southeast Atlantic cloud microphysics during the biomass burning season as seen by the A-train satellite constellation, J. Geophys. Res.-Atmos., 119, 11288-11302, https://doi.org/10.1002/2014JD022182, 2014.

Pistone, K., Redemann, J., Doherty, S., Zuidema, P., Burton, S., Cairns, B., Cochrane, S., Ferrare, R., Flynn, C., Freitag, S., Howell, S. G., Kacenelenbogen, M., LeBlanc, S., Liu, X., Schmidt, K. S., Sedlacek III, A. J., Segal-Rozenhaimer, M., Shinozuka, Y., Stamnes, S., van Diedenhoven, B., Van Harten, G., and Xu, F.: Intercomparison of biomass burning aerosol optical properties from in situ and remote-sensing instruments in ORACLES-2016, Atmos. Chem. Phys., 19, 9181-9208, https://doi.org/10.5194/acp-19-9181-2019, 2019.

Redemann, J., Wood, R., Zuidema, P., Doherty, S. J., Luna, B., LeBlanc, S. E., Diamond, M. S., Shinozuka, Y., Chang, I. Y., Ueyama, R., Pfister, L., Ryoo, J., Dobracki, A. N., da Silva, A. M., Longo, K. M., Kacenelenbogen, M. S., Flynn, C. J., Pistone, K., Knox, N. M., Piketh, S. J., Haywood, J. M., Formenti, P., Mallet, M., Stier, P., Ackerman, A. S., Bauer, S. E., Fridlind, A. M., Carmichael, G. R., Saide, P. E., Ferrada, G. A., Howell, S. G., Freitag, S., Cairns, B., Holben, B. N., Knobelspiesse, K. D., Tanelli, S., L’Ecuyer, T. S., Dzambo, A. M., Sy, O. O., McFarquhar, G. M., Poellot, M. R., Gupta, S., O'Brien, J. R., Nenes, A., Kacarab, M. E., Wong, J. P. S., Small-Griswold, J. D., Thornhill, K. L., Noone, D., Podolske, J. R., Schmidt, K. S., Pilewskie, P., Chen, H., Cochrane, S. P., Sedlacek, A. J., Lang, T. J., Stith, E., Segal-Rozenhaimer, M., Ferrare, R. A., Burton, S. P., Hostetler, C. A., Diner, D. J., Platnick, S. E., Myers, J. S., Meyer, K. G., Spangenberg, D. A., Maring, H., and Gao, L.: An overview of the ORACLES (ObseRvations of Aerosols above CLouds and their intEractionS) project: aerosol-cloud-radiation interactions in the Southeast Atlantic basin, Atmos. Chem. Phys. Discuss., https://doi.org/10.5194/acp-2020-449, in review, 2020.

Reynolds, R. W., Smith, T. M., Liu, C., Chelton, D. B., Casey, K. S., and Schlax, M. G.: Daily High-Resolution-Blended Analyses for Sea Surface Temperature, J. Climate, 20, 5473-5496, https://doi.org/10.1175/2007JCLI1824.1, 2007.

Ridley, J. K., Blockley, E. W., Keen, A. B., Rae, J. G. L., West, A. E., and Schroeder, D.: The sea ice model component of HadGEM3-GC3.1, Geosci. Model Dev., 11, 713-723, https://doi.org/10.5194/gmd-11-713-2018, 2018.

Roberts, G., Wooster, M. J., and Lagoudakis, E.: Annual and diurnal african biomass burning temporal dynamics, Biogeosciences, 6 , 849-866, https://doi.org/10.5194/bg-6-849-2009, 2009.
Sakaeda, N., Wood, R. and Rasch, P. J.: Direct and semidirect aerosol effects of southern African biomass burning aerosol, J. Geophys. Res.-Atmos., 116, D12205, https://doi.org/10.1029/2010JD015540, 2011.

Sellar, A. A., Jones, C. G., Mulcahy, J. P., Tang, Y., Yool, A., Wiltshire, A., O'Connor, F. M., Stringer, M., Hill, R., Palmieri, J., Woodward, S., Mora, L. de, Kuhlbrodt, T., Rumbold, S. T., Kelley, D. I., Ellis, R., Johnson, C. E., Walton, J., Abraham, N. L., Andrews, M. B., Andrews, T., Archibald, A. T., Berthou, S., Burke, E., Blockley, E., Carslaw, K., Dalvi, M., Edwards, J., Folberth, G. A., Gedney, N., Griffiths, P. T., Harper, A. B., Hendry, M. A., Hewitt, A. J., Johnson, B., Jones, A., Jones, C. D., Keeble, J., Liddicoat, S., Morgenstern, O., Parker, R. J., Predoi, V., Robertson, E., Siahaan, A., Smith, R. S., Swaminathan, R., Woodhouse, M. T., Zeng, G., and Zerroukat, M.: UKESM1: Description and Evaluation of the U.K. Earth System Model, J. Adv. Model. Earth Sy., 11, 4513-4558, https://doi.org/10.1029/2019MS001739, 2019.

Shinozuka, Y., Saide, P. E., Ferrada, G. A., Burton, S. P., Ferrare, R., Doherty, S. J., Gordon, H., Longo, K., Mallet, M., Feng, Y., Wang, Q., Cheng, Y., Dobracki, A., Freitag, S., Howell, S. G., LeBlanc, S., Flynn, C., Segal-Rosenhaimer, M., Pistone, K., Podolske, J. R., Stith, E. J., Bennett, J. R., Carmichael, G. R., da Silva, A., Govindaraju, R., Leung, R., Zhang, Y., Pfister, L., Ryoo, J.-M., Redemann, J., Wood, R., and Zuidema, P.: Modeling the smoky troposphere of the southeast Atlantic: a comparison to ORACLES airborne observations from September of 2016, Atmos. Chem. Phys., 20, 11491-11526, https://doi.org/10.5194/acp-20-11491-2020, 2020.

Stier, P., Schutgens, N. A. J., Bellouin, N., Bian, H., Boucher, O., Chin, M., Ghan, S., Huneeus, N., Kinne, S., Lin, G., Ma, X., Myhre, G., Penner, J. E., Randles, C. A., Samset, B., Schulz, M., Takemura, T., Yu, F., Yu, H., and Zhou, C.: Host model uncertainties in aerosol radiative forcing estimates: results from the AeroCom Prescribed intercomparison study, Atmos. Chem. Phys., 13, 3245-3270, https://doi.org/10.5194/acp-13-3245-2013, 2013.

Storkey, D., Blaker, A. T., Mathiot, P., Megann, A., Aksenov, Y., Blockley, E. W., Calvert, D., Graham, T., Hewitt, H. T., Hyder, P., Kuhlbrodt, T., Rae, J. G. L., and Sinha, B.: UK Global Ocean GO6 and GO7: a traceable hierarchy of model resolutions, Geosci. Model Dev., 11, 3187-3213, https://doi.org/10.5194/gmd-11-3187-2018, 2018.

Telford, P. J., Braesicke, P., Morgenstern, O., and Pyle, J. A.: Technical Note: Description and assessment of a nudged version of the new dynamics Unified Model, Atmos. Chem. Phys., 8, 17011712, https://doi.org/10.5194/acp-8-1701-2008, 2008.

Twomey, S.: Pollution and the planetary albedo, Atmos. Environ, 8, 1251-1256, 1974.

Twomey, S.: The influence of pollution on the shortwave albedo of clouds, Journal of the atmospheric sciences, 34(7), 1149-1152, 1977.

van der Werf, G. R., Randerson, J. T., Giglio, L., Collatz, G. J., Mu, M., Kasibhatla, P. S., Morton, D. C., DeFries, R. S., Jin, Y., and van Leeuwen, T. T.: Global fire emissions and the contribution of deforestation, savanna, forest, agricultural, and peat fires (1997-2009), Atmos. Chem. Phys., 10, 11707-11735, https://doi.org/10.5194/acp-10-11707-2010, 2010.

Walters, D., Baran, A. J., Boutle, I., Brooks, M., Earnshaw, P., Edwards, J., Furtado, K., Hill, P., Lock, A., Manners, J., Morcrette, 
C., Mulcahy, J., Sanchez, C., Smith, C., Stratton, R., Tennant, W., Tomassini, L., Van Weverberg, K., Vosper, S., Willett, M., Browse, J., Bushell, A., Carslaw, K., Dalvi, M., Essery, R., Gedney, N., Hardiman, S., Johnson, B., Johnson, C., Jones, A., Jones, C., Mann, G., Milton, S., Rumbold, H., Sellar, A., Ujiie, M., Whitall, M., Williams, K., and Zerroukat, M.: The Met Office Unified Model Global Atmosphere 7.0/7.1 and JULES Global Land 7.0 configurations, Geosci. Model Dev., 12, 1909-1963, https://doi.org/10.5194/gmd-12-1909-2019, 2019.

Watson-Parris, D., Schutgens, N., Cook, N., Kipling, Z., Kershaw, P., Gryspeerdt, E., Lawrence, B., and Stier, P.: Community Intercomparison Suite (CIS) v1.4.0: a tool for intercomparing models and observations, Geosci. Model Dev., 9, 3093-3110, https://doi.org/10.5194/gmd-9-3093-2016, 2016.

Watson-Parris, D., Schutgens, N., Reddington, C., Pringle, K. J., Liu, D., Allan, J. D., Coe, H., Carslaw, K. S., and Stier, P.: In situ constraints on the vertical distribution of global aerosol, Atmos. Chem. Phys., 19, 11765-11790, https://doi.org/10.5194/acp-1911765-2019, 2019.

Wilcox, E. M.: Stratocumulus cloud thickening beneath layers of absorbing smoke aerosol, Atmos. Chem. Phys., 10, 1176911777, https://doi.org/10.5194/acp-10-11769-2010, 2010.

Wilcox, E. M.: Direct and semi-direct radiative forcing of smoke aerosols over clouds, Atmos. Chem. Phys., 12, 139-149, https://doi.org/10.5194/acp-12-139-2012, 2012.

Wood, R.: Cancellation of Aerosol Indirect Effects in Marine Stratocumulus through Cloud Thinning, J. Atmos. Sci., 64, 26572669, https://doi.org/10.1175/JAS3942.1, 2007.
Wood, R.: Stratocumulus Clouds, Mon. Weather Rev., 140, 23732423, https://doi.org/10.1175/MWR-D-11-00121.1, 2012.

Woodward, S.: Modeling the atmospheric life cycle and radiative impact of mineral dust in the Hadley Centre climate model, J. Geophys. Res.-Atmos., 106, 18155-18166, https://doi.org/10.1029/2000JD900795, 2001.

Yamaguchi, T., Feingold, G., Kazil, J., and McComiskey, A.: Stratocumulus to cumulus transition in the presence of elevated smoke layers, Geophys. Res. Lett., 42, 10478-10485, https://doi.org/10.1002/2015GL066544, 2015.

Zhang, K., Wan, H., Liu, X., Ghan, S. J., Kooperman, G. J., Ma, P.-L., Rasch, P. J., Neubauer, D., and Lohmann, U.: Technical Note: On the use of nudging for aerosol-climate model intercomparison studies, Atmos. Chem. Phys., 14, 8631-8645, https://doi.org/10.5194/acp-14-8631-2014, 2014.

Zhou, X., Ackerman, A. S., Fridlind, A. M., Wood, R., and Kollias, P.: Impacts of solar-absorbing aerosol layers on the transition of stratocumulus to trade cumulus clouds, Atmos. Chem. Phys., 17, 12725-12742, https://doi.org/10.5194/acp-17-127252017, 2017.

Zuidema, P., Sedlacek, A. J., Flynn, C., Springston, S., Delgadillo, R., Zhang, J., Aiken, A. C., Koontz, A., and Muradyan, P.: The Ascension Island Boundary Layer in the Remote Southeast Atlantic is Often Smoky, Geophys. Res. Lett., 45, 4456-4465, https://doi.org/10.1002/2017GL076926, 2018. 